\title{
WHY BATS MATTERS: A CRITICAL ASSESSMENT OF BAT-MEDIATED ECOLOGICAL PROCESSES IN THE NEOTROPICS
}

\author{
Dennis Castillo-FigueroA ${ }^{1 *}$ \\ ${ }^{1}$ Pontificia Universidad Javeriana. Unidad de Ecología y Sistemática (UNESIS), \\ Departamento de Biología. Carrera 7 No. 43-82, 11001000, Bogotá, D.C., Colombia
}

Abstract.

New World bats play a significant role in ecosystem functioning and are imperative for maintaining environmental services. Nevertheless, human-caused environmental changes are jeopardizing bat communities, which results in the loss of functional roles provided by them. It is important, therefore, to assess ecological processes performed by bats in the Neotropics to define priorities in further research for better conservation planning. In this systematic review, I identify general trends, advances, bias, and knowledge gaps in bat-mediated ecological processes across Neotropical ecosystems. I have conducted an extensive search on Google Scholar, Scopus, Web of Science, and Bat Eco-Interactions Database resulting in 538 references, of which 185 papers were included in the review. The papers were published in 76 peer-reviewed journals, with the highest peak between 2006-2010. From the six biomes recorded, Moist broadleaf tropical forest was the most researched, contrary to Montane biomes (>2000 m), where few studies have been conducted. Seed dispersal was the process with more studies (44\%), followed by pollination (38\%), nutrient cycling (10\%), and arthropod suppression (8\%). Seed dispersal and pollination displayed large bias on specific bat-plant systems (Artibeus-Ficus, Sturnira-Solanum, Carollia-Piper, Pachycereeae tribe-Leptonycteris) and ecoregions (Ithsmian-Atlantic moist forest, Cerrado, Tehuacán Valley matorral), thus being important to explore other bat and plant species as well as other ecosystems. Arthropod suppression and nutrient cycling were largely overlooked despite constituting essential functions in ecosystem resilience; particularly, more research is needed to know cascading effects on plant fitness in different agroforestry systems, but also is key the understanding of how bats can be pivotal mobile links in terrestrial ecosystems and cave environments. I highlight the importance to consider bats with multiple roles and functional trait-based approach to gain a comprehensive understanding of their functionality. Even though functional studies have increased in the last two decades, several aspects of bat roles are still obscured, and is necessary to keep evaluating their ecological and economic importance to provide useful information for major decision-makings in Neotropical ecosystems' conservation. Bat extirpations are likely to affect their ecological roles, therefore, mitigating major threats of bats are urgently needed to sustain ecosystem integrity in the Neotropics.

Key words: Chiroptera; Ecosystems; Neotropical Region; Functional roles; Seed dispersal; Pollination; Nutrient cycling; Arthropod suppression; Functional trait; New World Bats.

\section{INTRODUCTION}

In the last few decades, the relationship between biodiversity and ecosystem functioning has become a key framework for understanding species' roles in the provision of ecosystem services (Luck et al. 2009; Cadotte et al. 2011; Luck et al. 2012). In an era with unprecedented rates of biodiversity loss at global scale (Johnson et al. 2017; Ceballos et al. 2017), the study of ecological processes and functional roles of species in the ecosystems becomes critical for major decision-making in conservation planning (Díaz \& Cabido 2001; Cadotte et al. 2011; Córdova-Tapia \& Zambrano 2015). However, functional roles performed by species, especially in animals, have frequently been inferred from ecological interactions that not necessarily entails a contribution to ecological process as such.

It is well-recognized the central role of mammals in mediating ecological processes such as seed dispersal, seed predation, pollination, pest control, energy flow, predation, herbivory, and ecosystem engineering (Lacher et al. 2019). Within mammals, bats are, undoubtedly, one of the most important taxa since represent the highest number of species after rodents, which means for about $21.89 \%$ of all the mammalian richness (Mammal Diversity Database 2020). Furthermore, bats display a high ecological diversity because are involved in multiple trophic interactions (Kasso \& Balakrishnan 2013), thus contributing to a variety of ecosystem services (Kunz et al. 2011). The 
global conservation status of bats, nevertheless, is a major concern because, on one hand, a third of bats assessed by International Union for Conservation of Nature (IUCN) are considered either threatened or data deficient, and on the other hand, over half of the species are ranked with either unknown or decreasing population trends (Frick et al. 2019). Importantly, the Neotropics is a priority region of conservation attention for bats (Frick et al. 2019), but the pervasive lack of data about bat ecology has partially hampered conservation actions across the region.

New world bats are particularly important in maintaining ecosystem health throughout the provision of ecological functions, including forest regeneration via seed dispersal (Galindo-González et al. 2000; Muscarella \& Fleming 2007), plant reproduction prompted by pollination (Aguilar-Rodríguez et al. 2014; Tremlett et al. 2019), pest control caused by arthropod suppression (Kalka et al. 2008; Karp \& Daily 2014), and nutrient cycling via guano and urine deposition (Voigt et al. 2015). Despite the numerous studies that have parsed out bat-plant interactions in the Neotropics, the quantification of real functions performed by bats seems to be fuzzy and not comprehensive. Summarizing the information about functional contributions of bats, therefore, may be useful to evaluate the advances in the study of ecological processes, identify gaps of knowledge, and define priorities in future ecological research.

The Neotropical region is, probably, the most complex biotic realm of the world because of its vast extension of forests, but also for its tremendous taxonomic, phylogenetic, and functional diversity (Antonelli et al. 2018; Rull \& Carnaval 2020). Indeed, ecosystems like Neotropical rain forests represent the highest animal and plant diversity of all terrestrial ecosystems (Olson and Dinerstein et al. 2002; Rex et al. 2011). Other biomes from this region such as Mountain forests are recognized by their striking patterns of endemism (Orme et al. 2005), but many components of ecosystem functioning remain poorly explored in comparison to other biomes from lower elevations. Nonetheless, the Neotropical realm is one of the most threatened regions due to marked anthropogenic pressures (González-Maya et al. 2017). Considering the current rates of bat extinction (Frick et al. 2019), and that human-induced impacts are likely to increase in the coming years (Arroyo-Rodríguez et al. 2017), it is necessary to assess bat-mediated functional roles across the Neotropics to provide key information for future ecological and economic valuation that allows designing better conservation planning.

In this paper, I analyzed the main ecological processes performed by bats (i.e. seed dispersal, pollination, arthropod suppression, and nutrient cycling) across Neotropical ecosystems, describing the bibliographical, spatial, and ecological information of each function. By doing so, I assessed quantitatively the current understanding of ecological processes provided by Neotropical bats, highlighting gaps of knowledge, remarkable advances and future challenges in bat functional research.

\section{Materials and Methods Data Searching and Exclusions}

On December 2019 I conducted an extensive revision through Google Scholar, Scopus, and Web of Science searching for the available scientific literature that contained in the title, abstract, and/or keywords the following search terms with all the possible combinations: ("Bats" OR "Chiroptera" OR "Flying mammals") AND ("food habit" OR "diet" OR "frugivory" OR "seed dispersal" OR "seed ingestion" OR "dispersers" OR "chiropterocory" OR "nectarivory" OR "pollination" OR "flower" OR "nectar" OR "chiropterophily" OR "foraging” OR "predation" OR "consumption" OR "biological control" OR "insect control" OR "mosquito control" OR "ecosystem function" OR "ecological function" OR "ecological process" OR "functional group" OR "ecological group" OR "role") AND ("Neotropics" OR "Neotropical" OR "New world"). I also searched for references in the Bat Eco-Interactions Database (Geiselman et al. 2015) and the papers referenced in the articles selected. Thus, I included all the possible references without time restriction (up to December 2019). The Google Scholar search produced 100 pages of results, which were completely revised.

After eliminating the duplicated documents, and Gray literature (e.g. thesis, congress memories, and technical reports), I evaluated all the references according to the following inclusion criteria by reviewing the title, key words and abstract: (1) the organisms investigated were Neotropical bats regardless where the study was conducted and (2) papers' topics were related to seed dispersal, pollination, arthropod suppression or nutrient cycling, as these are the main functions recognized in bats (Kasso \& Balakrishnan 2013) (Fig. S1 in supplementary material). Posterior- 
ly, reading the full text, I removed the references that: (1) were based mainly on bat ecomorphology, plant phylogeny, theoretical ecology, and evolutionary biology because those themes are marginally related to ecosystem functioning approach and (2) included only trophic interactions between bat-flowers, batfruits or bat-insects such as dietary studies because they don't assess effectively the process (Fig. S1 in supplementary material). Thus, I gathered research studies that directly assess the ecological roles performed by Neotropical bats either empirically (i.e. field studies, experiments) or analytically (i.e. meta-analyses or reviews).

\section{Data analyses}

I organized the Information derived from the references in Microsoft Excel 2016 by using mainly cross-tabulations. From each document, I compiled information according to the following features: (a) Bibliographic information (year, type of publication, type of study, journal, the disciplinary topic of the study) (b) Spatial information (country and city/state of the study, altitude, biome and ecoregion) (c) Ecological processes information (function assessed, component of the process assessed, variables analyzed, methods employed, and effects

(a)



(c)



evaluated). When a paper covered different features (e.g. topics, functions, variables, etc.), each feature was considered separately. Altitude was searched in Google Earth when the study did not provide it, and biomes and ecoregions were obtained from locations described in the study areas, which were assigned according to Ecoregions 2017 (C) Resolve (Olson et al. 2001; Dinerstein et al. 2017).

I quantified the percentage of publications to each feature with a respective number of studies (n). To assess publication rates and correlations of the number of papers to altitude, I regressed the percentage of publications to years and elevation, respectively. These analyses were carried out using Rwizard 4.3 (Guisande et al. 2014).

\section{Results \\ General trends}

Keyword search identified 538 references. After a detailed analysis of each paper, 185 were considered for the purpose of this study (Fig. S1 in supplementary material). The number of publications increased importantly since the start of the new millennium $\left(P<0.0001, \mathrm{R}^{2}=0.47\right.$, Fig. 1a) with a noteworthy peak in the period time between 2006-2010 $(\mathrm{n}=44)$. Studies were published in 76 peer-reviewed (b)

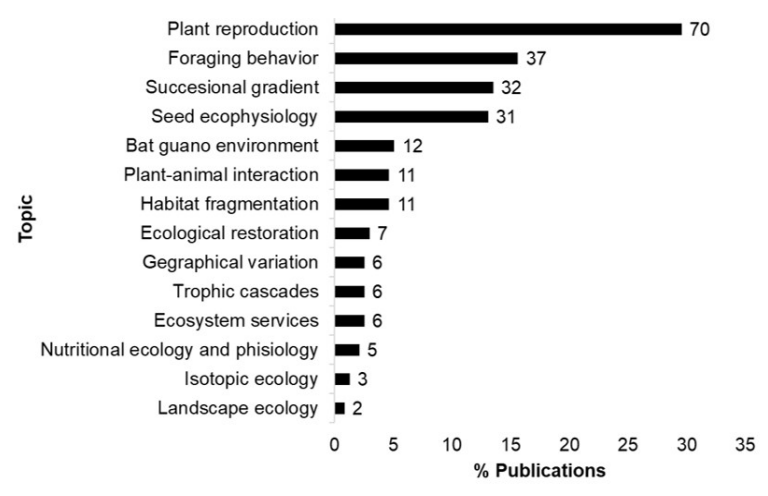

(d)



- Original article $\quad$ Short communications $\quad$ Review article $\quad$ Book chapter

Figure 1. Bibliographical information of bat-mediated ecological processes in the Neotropics showing: (a) years (b) topics (c) study type (d) type of document. The number of studies is presented on the side of each bar. 
journals (Table S1 in supplementary material). The journals with the largest number of publications were Biotropica $(n=18)$, American Journal of Botany $(n=$ 17), Journal of Tropical Ecology $(n=10)$, and Ecology $(\mathrm{n}=10)$. The main topics of the studies were plant reproduction $(n=70)$, foraging behavior $(n=37)$, successional gradient $(\mathrm{n}=32)$ and seed ecophysiology $(\mathrm{n}=31)$ (Fig. 1b). Regarding study type, most were empirical-experimental $(n=73)$, empirical (n $=58)$ and experimental $(\mathrm{n}=32)($ Fig. 1c) and the type of publications were mainly original articles (n $=141)$ and short communications $(\mathrm{n}=22)$ (Fig. 1d).

Seed dispersal $(n=85)$ and pollination $(n=73)$ were by far the most investigated bat-mediated ecological processes, whereas nutrient cycling $(n=20)$ and arthropod suppression $(\mathrm{n}=16)$ received less attention (Fig. 2a). Over the 13 Neotropical countries where bat ecological roles were investigated, México presented more studies $(\mathrm{n}=47)$ followed by Brazil $(n=43)$. In the former, more research was conducted in pollination $(\mathrm{n}=28)$ and in the latter more seed dispersal studies were performed $(n=22)$ (Fig. $2 b)$. From the six world biomes found in the systematic review, Moist broadleaf tropical forest showed most functional studies ( $\mathrm{n}=89,52.66 \%$ ) (Fig. 2c). Across the 54 ecoregions selected to perform the studies, Ithsmian-Atlantic moist forest in Costa Rica and
Panamá $(\mathrm{n}=18,10.22 \%)$, Cerrado in Brazil $(\mathrm{n}=17$, $9.65 \%)$, Tehuacán Valley matorral in Mexico $(\mathrm{n}=10$, 5.68\%) and Central American Dry Forest in Costa Rica $(\mathrm{n}=10,5.68 \%)$ were the most frequent study sites. Following an inverse function, I found a significant relationship between altitude and the number of publications $\left(P<0.0001, \mathrm{R}^{2}=0.92\right.$, Fig. 2 d), with more than the $70 \%$ of the studies carried out up from 0 to 600 m elevation $(n=94)$.

\section{Seed dispersal}

Seed rain $(n=52)$ and seed germination $(n=35)$ were the components assessed when evaluated seed dispersal performed by bats (Fig. 3a). Within variables employed to make an appraisal of seed rain, species richness of seeds dispersed $(n=25)$, seed density $(\mathrm{n}=19)$, and disperser importance index ( $\mathrm{n}$ $=8$ ) were the most frequent variables analyzed (Fig. $3 b)$. For seed germination component, the variables most commonly studied were germination percentage $(n=26)$, germination rate $(n=12)$ mean germination time $(\mathrm{n}=6)$ (Fig. 3b). Habitat comparison $(\mathrm{n}=25)$ and germination experiments $(\mathrm{n}=30)$ were the principal methods for studying both components of the functions. Exclosure experiments were lesser employed $(n=2,3.3 \%)$. The principal effects tested comprised animal ingestion (bats and control), (a)



(b)



(c)



(d)

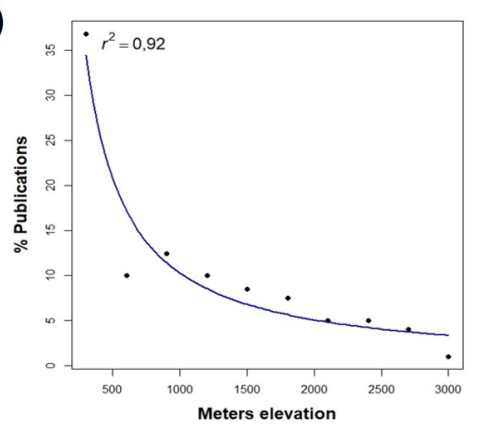

Figure 2. Spatial information of bat-mediated ecological processes in the Neotropics showing: (a) ecological processes (b) country (c) biome (d) elevation. Colors of the bars indicate the ecological process studied. 
(a)



(b)

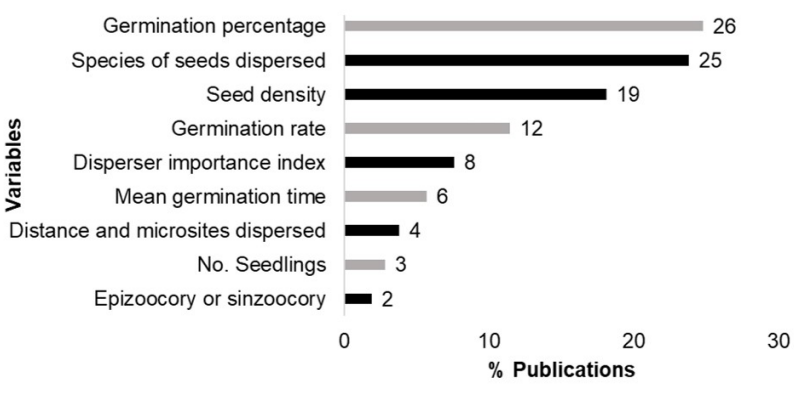

(c)

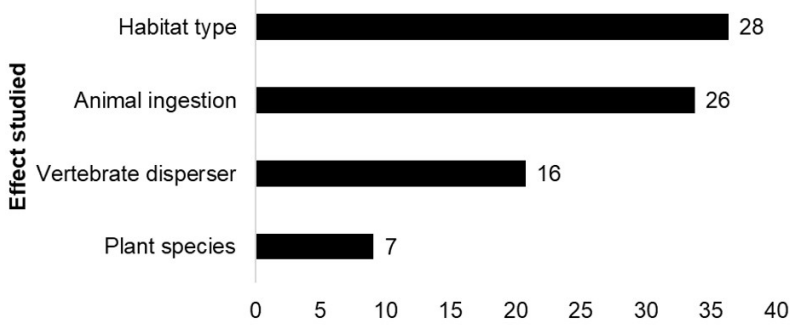

Figure 3. Seed dispersal performed by Neotropical bats: (a) component of the process assessed (b) variables (c) effects used in the studies. Colors of the variables are associated to the component studied. The number of studies is presented on the side of each bar.

habitat type (forest, edges, open areas and forests with different successional stages), vertebrate seed disperser (bats and birds), and plant species (germination treatments testing the responses of different seed species ingested by the same frugivorous bat) (Fig. 3c). In these investigations, Artibeus, Carollia, Platyrrhinus, and Sturnira were the bat genera with more studies ( $\mathrm{n}=49,83 \%)$, and Ficus, Piper, Cecropia and Solanum the plant genera dispersed more frequently by them.

\section{Pollination}

Pollination was heavily investigated in the component of effectiveness $(n=63)$, but very few studies were carried out in terms of plant genetics $(n=5)$ (Fig. 4a). Variables such as fruit set $(\mathrm{n}=49)$, seed set $(n=36)$, and pollen deposited $(n=14)$ were the most employed when analyzing pollination effectiveness (Fig. 4b). Outcrossing rate $(\mathrm{n}=2)$ and genetic diversity $(n=5)$ were the variables used for examining the effect of bat pollination on plant genetics (Fig. 4b). Main effects parsed out in the studies constituted pollinator group (diurnal birds, diurnal insects, nocturnal insects, nocturnal mammals), breeding system (self-pollination, outcrossing pollination, etc.), plant species (bat pollination in different plant species), populations (bat pollination in different plant populations of the same species), bat species (pollination of the same plant species performed by different bat species), and habitat type (fragmented, disturbed, natural) (Fig. 4c). Experimental exclosure ( $\mathrm{n}=37,72.5 \%)$ was the main study design in the evaluation of this process. In general, Leptonycteris, Choeroniscus, Anoura, and Glossophaga were the most studied bat genera $(n=51,88 \%)$. Pachycereeae tribe which comprises columnar cacti such as Stenocereus, Pachycereus, and Carnaegiea were the most common plants studied in bat pollination systems.

\section{Arthropod suppression}

Reduction of herbivory $(\mathrm{n}=6)$ and arthropod predation $(\mathrm{n}=9)$ were the two aspects analyzed for arthropod suppression (Fig. 5a). In the former, variables included arthropod biomass $(n=5)$ and economic savings provided by bats $(\mathrm{n}=3)$, and in the latter, leaf damage $(n=3)$, leafs saved by bats $(n=1)$, leaf loss $(n=1)$, leafs attacked $(n=1)$ and fruit set $(\mathrm{n}=1)$ were analyzed (Fig. 5b). The studies included mainly comparisons between animal groups (bat vs birds), seasons (wet vs dry), agricultural management (traditional vs intensified), and bat exclusion (money invested to crops with bats and without them) (Fig. 5c). Experimental exclosure was the principal methodology to assess this process $(n=6,54.54 \%)$, but 
(a)

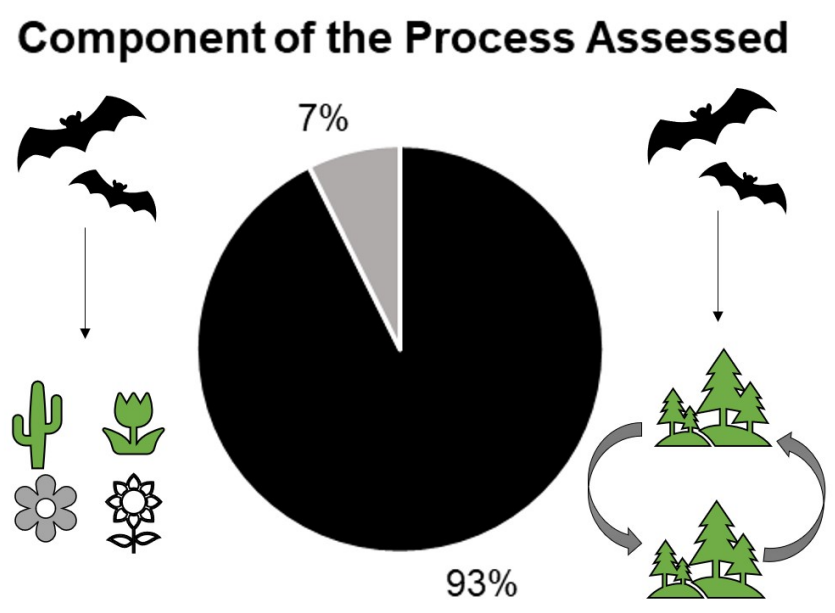

- Pollination effectiveness $\quad$ Plant genetics (b)



(c)

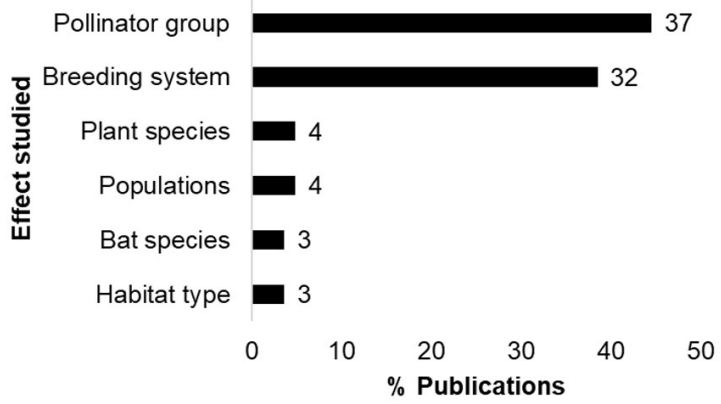

Figure 4. Pollination performed by Neotropical bats: (a) component of the process assessed (b) variables (c) effects used in the studies. Colors of the variables are associated to the component studied. The number of studies is presented on the side of each bar.

(a)

\section{Component of the Process Assessed}
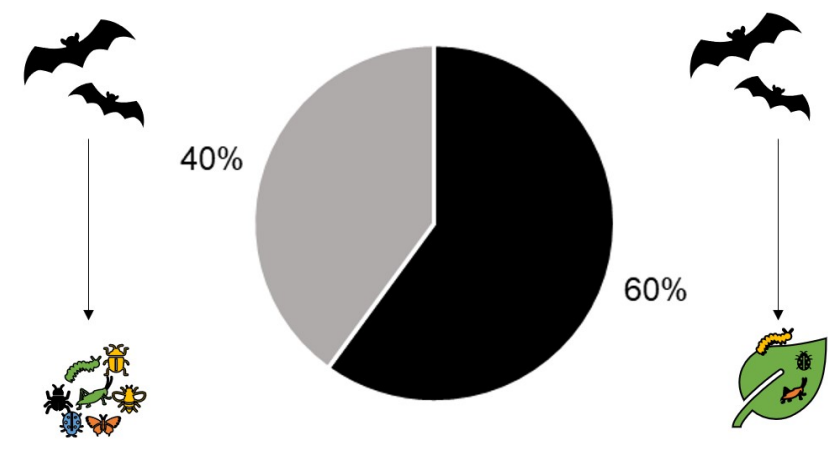

- Arthropod predation

- Reduction of Herbivory (b)



(c)



Figure 5. Arthropod suppression performed by Neotropical bats: (a) component of the process assessed (b) variables (c) effects used in the studies. Colors of the variables are associated to the component studied. The number of studies is presented on the side of each bar.

the ecosystem services approach was also important $(\mathrm{n}=3,27.27 \%)$. Overall, bats effect on the reduction of herbivory was evaluated through field exclusion experiments. Only Tadarida brasiliensis Geoffroy, 1824, and Micronycteris microtis Miller, 1898 were assessed individually by using the ecosystem services approach and foraging studies. Eight plant species were evaluated in the reduction of herbivory component: Hybanthus prunifolius (Humb. \& Bonpl. ex Schult.) Schulze-Menz, Psychotria horizon- 
talis Sw., Acalypha diversifolia Jacq., Croton billbergianus Müll. Arg., Miconia argentea (Sw.) DC., Coffea arabica L., Theobroma cacao L., Inga edulis Mart.). Of these, two are species of high economic interest for agriculture (coffee and cacao).

\section{Nutrient cycling}

Nutrient budgets $(\mathrm{n}=9)$ and bat guano environment $(n=11)$ were the two components assessed in nutrient cycling process (Fig. 6a). Nutrient concentration $(n=6)$, stable isotopes $(n=2)$, and soil fertilization were the variables measured in nutrient cycling analysis, whereas invertebrate abundance (n $=8)$ and species richness $(\mathrm{n}=10)$ were the variables measured to study bat guano environment (Fig. 6b). The effects analyzed in the studies included bat guild (bat guano from frugivorous, insectivorous and hematophagous), individual state (male, female, reproductive stage), and bat roost (natural and artificial, distance to roost) (Fig. 6c). Bat guano sampled manually from caves was the principal method for studying both components of the function $(n=12)$. Bat species with more studies that analyzed bat guano were Eptesicus fuscus Palisot de Beauvois, 1796, and Desmodus rotundus Geoffroy, 1810 ( $\mathrm{n}=7,41.17 \%$ ). Other species analyzed included insectivores such as T. brasiliensis and Myotis velifer Allen, 1890, frugivorous from the genus Carollia, Platyrrhinus,
Uroderma, Sturnira and omnivorous from the genus Phyllostomus and Tonatia.

\section{Discussion \\ General advances}

The systematic review addressing ecological roles performed by Neotropical bats revealed a growing scientific production over the last two decades. However, I identified a large bias in the distribution of studies in terms of topics, study types, biomes, and altitude. The bulk of papers came from botanical studies of pollination, foraging behavior of bats, and successional gradients of secondary forests (Fig. 1b). This is reflected in the type of journals where the studies were published (botanical and ecological journals) and, more importantly, the conceptual perspective from which this body of literature was produced. That is, discussions of successional gradients, as well as pollination, have traditionally focused on plants (Muscarella \& Fleming 2007; Fleming et al. 2009). Nevertheless, in recent decades the focus has changed from merely botanical studies to comprehensive plant-animal interactions with the remarkable technological advances both in animal and plant ecology (e.g. radiotracking, video recording, molecular techniques). Further, the implementation of field exclosure experiments have allowed to differentiate the effect of bats between controls, other groups of (a)

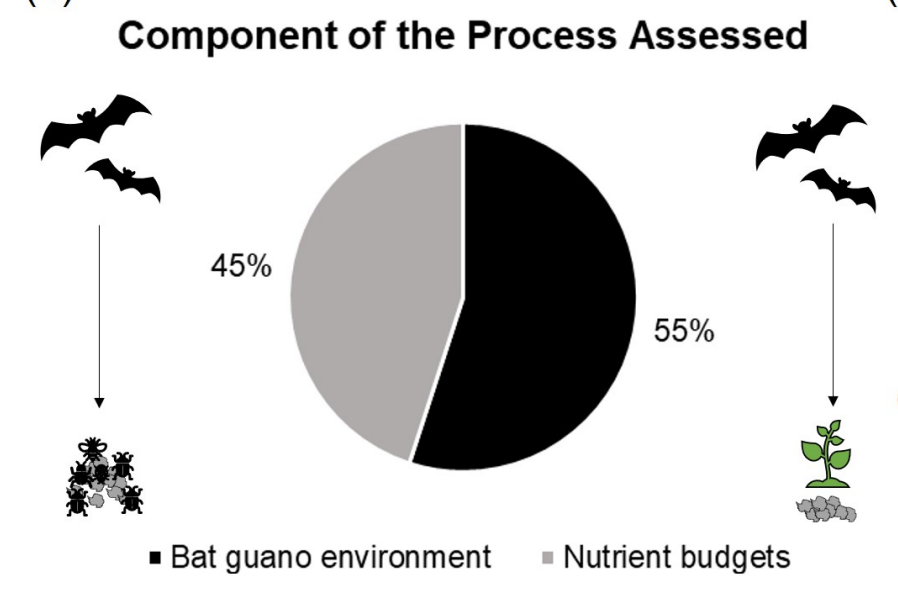

(b)

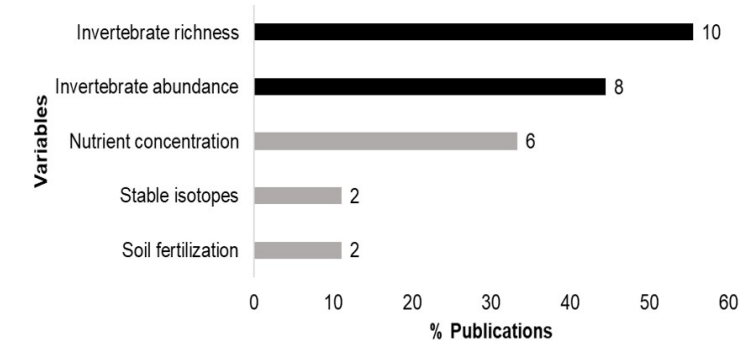

(c)

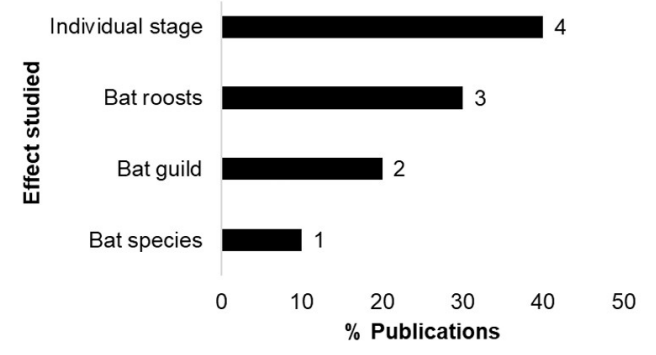

Figure 6. Nutrient cycling performed by Neotropical bats: (a) component of the process assessed (b) variables (c) effects used in the studies. Colors of the variables are associated to the component studied. The number of studies is presented on the side of each bar. 
animals, and combined effects on important functions such as pollination (Santiago-Hernández et al. 2019), and arthropod suppression (Maas et al. 2019).

In sharp contrast, I found very few studies in mountain forests $(>2000 \mathrm{~m})$ compared to lowland moist forests $(<500 \mathrm{~m})$ (Fig. 2d). Biological research institutes and field stations have played a key role in the research of functional ecology in Neotropical ecosystems (Guariguata \& Kattan 2002). Well-recognized research centers such as La Selva in Costa Rica, Barro Colorado in Panamá, Los Tuxtlas in Mexico, and several research institutions in Brazil have heavily contributed to understanding ecosystem functioning of tropical lowland forests. Notwithstanding, other biomes and ecoregions placed in highland forests such as Montane grasslands and Shrublands across the Andes remains little investigated. Due to rapid-human transformation (Orme et al. 2005; Etter et al. 2008), extraordinary local endemism and high rates of Beta-diversity in Andes Mountains (Olson \& Dinerstein 2002), this region offers an interesting scenario for studying bat ecological roles under dynamic ecosystems.

\section{Seed dispersal}

Massive forest loss has resulted in a considerable expansion of secondary forest in the Neotropics (Brown \& Lugo 1990; Hansen et al. 2013; Chazdon et al. 2016; Arroyo-Rodríguez et al. 2017). Therefore, the study of natural regeneration has become a critical topic in conservation biology and restoration ecology, in which bats perform a central role. On one hand, bats disperse large quantities of seeds in a variety of microsites, including open areas avoided by other dispersers, thus influencing forest structure and composition as well as regeneration and successional patterns (Galindo-González et al. 2000; Muscarella \& Fleming 2007; Henry \& Joudard 2007; Cole et al. 2010). On the other hand, despite seed ingestion by bats do not enhance germination in general (Saldaña-Vázquez et al. 2019), viable seeds ingested are likely to be deposited at sites suitable for germination (Carvalho-Ricardo et al. 2014). Due to this, bats have a pivotal effect during ecological succession, especially in the first stages of forest recovery (Muscarella \& Fleming 2007), therefore the interest on chiropterocory has been a matter of significant importance under the accelerated rates of landscape transformation (Fig. 2a).
Nonetheless, further research is needed on understanding physiological features of bats related to germination success such as gut retention time, digestive capacity, and gut size. Also, the effect of fruit secondary compounds on the digestive physiology of bats may provide a comprehensive explanation of germination rates (Baldwin \& Whitehead 2015). It should be noted, however, the large bias in seed germination experiments on very few bat genera including Artibeus, Carollia, Sturnira, and Platyrrhinus along with seeds like Cecropia, Ficus, Piper, and Solanum (Oliveira \& Lemes 2010; Oliveira et al. 2013; Carvalho-Ricardo et al. 2014; Carvalho et al. 2017). Since there are 22 genera of fruit-eating phyllostomid bats (Muscarella \& Fleming 2007), future research should examine germination in frugivorous bats other than the aforementioned genera. However, not only obligatory frugivores can disperse seeds (Laurindo et al. 2020). Interestingly, other feeding guilds like insectivorous and carnivorous bats have shown diets that include fruits and may contribute at some extent to seed dispersal (Aranguren et al. 2011; Novaes et al. 2015; Laurindo et al. 2020), therefore germination treatments could test seed dispersal effectiveness for these species also (but see below).

Importantly, Neotropical frugivorous bats can disperse a variety of seeds in different ways other than seed ingestion. For instance, tent-roosting bats can disperse a remarkable diversity of large seeds $(>8 \mathrm{~mm})$ in disturbed habitats, promoting forest regeneration and maintaining a high diversity of plant species (Melo et al. 2009; Villalobos-Chaves et al. 2020). It is unknown, however, to what extent Neotropical fruit bats can aid functional redundancy in forest ecosystems where large frugivorous have been extirpated (Melo et al. 2009). Finally, the dispersion of diaspores attached to the fur has been poorly documented in bats, albeit it is likely not significant in comparison to endozoochory (Lobova \& Mori 2004). Despite being a rare event, recording this kind of dispersion could complement our knowledge about seed dispersal performed by these mammals.

\section{Pollination}

Bats perform a prime function on plant fitness by enhancing their reproductive effectiveness in two essential components: (1) carrying a substantial amount of pollen on their bodies and depositing myriad of pollen grains on stigmas (Fleming et al. 
2009; Muchhala \& Thompson 2010) and (2) promoting outcrossing through carrying pollen over long distances among individuals, thus reducing levels of genetic subdivision between plant populations and, consequently, increasing the area of plant genetic neighborhoods (Fleming et al. 2009; Lacher et al. 2019). Given the general assumption in pollination studies of include all interactions of floral visitors as effective no matter the contribution to plant fitness (Santiago-Hernández et al. 2019), in this systematic review, I considered as pollination effectiveness only fruit production, seed production, and pollen delivery on stigmas (Fig. 4b). Visitation frequency is not necessarily an indicator of pollinator importance, since rare species may be more effective by bolstering seed set and fruit set (Santiago-Hernández et al. 2019).

The bulk of studies assessing effective pollination were focused on Pachycereeae tribe and its relationships between Leptonycteris, Glossophaga, and Choeroniscus species, however, other nectarivorous bats still lacks on proofs about their role on plant fitness of other species. Moreover, the vast majority of these papers were concentrated on Desert and Xeric environments of Mexico (Fig. 2b), and the resulting evidence suggest a dependence of cacti species on bats in Tehucacán Valley (center of diversity of Pachycereeae), but a more generalized pollinator systems in intertropical regions (Valiente-Banuet et al. 1996; Valiente-Banuet et al. 2004). Even though Southern Mexico represents one of the most diverse regions of dry forests and xeric environments worldwide (Olson \& Dinerstein 2002), for many regions of South America, however, bat-dependence on cacti or other related plants is understudied. New configurations between bats-flower systems can be discovered. To name a few examples, dry ecosystems of the Pacific coast of northwestern South America is characterized by unique species due to isolation (Olson \& Dinerstein 2002), but thus far little is known about their pollination systems. Additionally, dry valleys and Andean enclaves remain poorly understood despite represent an important genetic reservoir of species (Soriano \& Ruiz 2002).

A crucially urgent aspect of pollination ecology relies on the effect of bat activity on plant genetics since in this review less than $10 \%$ of studies assessed this component (Fig. 4a). It is important to clarify the impact of declines in bat populations on reductions in plant genetic diversity, especially in the flora of economic or ecological interest (Lacher et al. 2019), having that the bulk of vertebrate-pollinated plants display outcrossing breeding systems (Renner \& Ricklefs 1995).

\section{Arthropod suppression}

Insectivorous bats constitute the more representative trophic guild in terms of species richness in the Neotropics as well as in the other world regions (Maas et al. 2016). More broadly, because of their high mass-specific metabolic rates, bats are known to be voracious feeders of night-flying insects (Kalka et al. 2008; Kalka \& Kalko 2006; Lacher et al. 2019), a somewhat that is reflected in high feeding rates per night, which depending on the species and the season, may exceed $2 / 3$ of the bat body mass in insect biomass during mid-lactation (Kunz et al. 1995). Accordingly, arthropod suppression by bats exert topdown control, increasing plant fitness through the reduction of leaf damage (Kalka et al. 2008; Maas et al. 2016). It should be noted that several factors may influence the impact of bats on arthropod control; for instance, complex food webs in Neotropical ecosystems composed by different trophic levels (Karp \& Daily 2014; Cassano et al. 2016), seasons (Williams-Guillén et al. 2008; Karp \& Daily 2014), landscape context (Maas et al. 2019), and agricultural managements (Cassano et al. 2016) can modulate the final effect of bats on arthropod suppression.

Bats consume a broad spectrum of arthropod preys including herbivorous insects like caterpillars, beetles, and grasshoppers (Kalka \& Kalko 2006), but also predatory arthropods such as spiders and ants (Karp \& Daily 2014; Maas et al. 2016; Cassano et al. 2016). Both circumstances trigger cascading effects with different results on plant fitness; preying directly on herbivore pests benefit plants by reducing herbivory and, conversely, intraguild predation increase herbivory rates thus affecting plant survival. However, information in this regard is still limited and additional studies should assess cascading effects on different agricultural systems and landscapes managements across the Neotropical region. In particular, understanding how the spatial scale of analysis, either at local or landscape units, influences the effect of bats on herbivory is central to the design of effective conservation strategies (Librán-Embid et al. 2017).

Importantly, exclosure experiments were the main study design performed to test the impact of bats on pest control. Nonetheless, some biases can 
potentially underestimate the bat effect on arthropods. Firstly, aerial insectivores that capture their prey in the air during flight are far from plants assessed in the experiment (Maas et al. 2016). Secondly, mesh size of exclosures may filter insect species, excluding larger insect herbivores (Maas et al. 2016). Thirdly, using cages may change environmental conditions such as light, temperature, humidity, and wind, affecting leaf features and, either directly or indirectly, insect survival. Further studies should analyze these potential biases when evaluating bat impact on insect predation. Also, variables other than leaf damage that are directly related to crop yield, such as fruit set have been little measured and are likely to be important, especially on crops of economic interests (Fig. 5b). In this review, I only found one paper assessing fruit production in coffee plantation (Librán-Embid et al. 2017), hence I consider this variable should complement the standard measures of leaf damage in future research when evaluating this ecological process.

Approaches of ecosystem services provided by bats in pest control have stressed substantial economic savings in agricultural systems, suggesting the fundamental role of these mammals as an alternative to pesticides that pollute the environment and increase costs to human health and economical investment in crop management (Cleveland et al. 2006; Boyles et al. 2011; Maas et al. 2016). Nevertheless, in the revision, I only found this approach in the Brazilian freetailed bat (T. brasiliensis) (Cleveland et al. 2006) and a general estimation on fresh leaves saved per year by the action of the gleaning bat M. microtis (Kalka \& Kalko 2006). It is critical to quantify the economic and ecological contribution of insectivorous bats to Neotropical ecosystems, agroforestry systems, plantations, and agricultural lands. However, this is a challenging task considering the lack of knowledge in the natural history of several species in terms of dietary information.

\section{Nutrient cycling}

Besides the top-down effects, fecal deposition or guano generated by bats may have substantial bottom-up effects on terrestrial ecosystems (Emerson \& Roak 2007) by influencing vegetation patterns within forests (Duchamp et al. 2010). Overall, animals play a prime role in nutrient movement on ecosystems (Lundberg \& Morberg 2003; Doughty et al. 2016). Nutrient cycling has been studied mainly on large grazing mammals (e.g. ungulates) because of their importance on transporting macronutrients across several ecosystems and fertilizing nutrient-poor habitats (Lacher et al. 2019). Notwithstanding, bats can fertilize trees that are used as roosting sites, increasing nitrogen content in the tree soil and their seeds (Voigt et al. 2015). This is probably another type of mutualism between plants and bats that needs to be disentangled in the Neotropics as has been done in other regions. (Grafe et al. 2011).

Bearing in mind that connectivity between communities is sustained by the redistribution of biomass, often by mobile animals that translocate nutrients, for example, by consuming food resources in one habitat and subsequently urinate and defecate in other habitats (Lundberg \& Morberg 2003; Emerson $\&$ Roak 2007), bats are very important mobile links considering their high home range and commuting distances every night (Bernard \& Fenton 2003; Mello et al. 2008). Since primary production is limited by nutrients such as nitrogen and phosphorous (Vitousek \& Howarth 1991), bat guano is an essential input of nutrients and organic material that is still poorly known. Hot spot hypothesis establishes the potential effect of large bat colonies in the increase of nutrients (hot spot) by defecating within and nearby the roost tree (Pierson 1998; Duchamp et al. 2010). It should be noted, however, that I only found one paper testing this hypothesis in the Neotropics (Voigt et al. 2015). Also, I consider that not only bat guano is a source of nutrients but urine, which is understudied.

Considering the historical reductions in nutrient distribution capacity over worldwide (Doughty et al. 2016), coupled with the pivotal effects of mobile links in nutrient allocation (Lundberg \& Morberg 2003), the study of bat impact on nutrient cycling and redistribution in forests may provide not only a better understanding of ecosystem dynamics, but also may reinforce the idea of bats as natural fertilizers of forests. Hence, I find important to keep examining the relationship between soil fertility and trees that host bat colonies because is a function that has been largely neglected and is likely to have a considerable effect on nutrient allocation given the diversity of tree hollows used by bats (Kalko et al. 1999; Sampedro 2008; Garbino \& Tavares 2018). In addition, given the differences in nutrient concentration of bat guano between guilds, one would expect different functional consequences depending on the guild (Emerson \& Roak 2007). Such consequences can be analyzed at different scales ranging from changes in invertebrate 
diversity and food web dynamics in guano piles to effects on ecosystem processes such as decomposition and soil fertilization (Fig. 6b). Stable isotopes analysis can be helpful in this kind of study.

In particular, caves are ecosystems where bat guano represents a fundamental source of organic material from which complex food webs depend on (Gnaspini \& Trajano 2000). Bat guano can also be considered a variable biotope characterized by a mosaic of microhabitats that harbor diverse biotic communities ranging from bacteria and fungi decomposers to an extensive set of arthropods and invertebrate groups (Ferreira \& Martins 1999; Ferreira \& Martins 2007). Since bat guano is an ephemerous but paramount resource that sustains the biodiversity of cave environments, alteration on bat community structure is likely to have profound impacts on invertebrate communities (Salgado et al. 2014). Nevertheless, the current evidence on the trophic structure of bat guano communities is largely biased in Brazilian caves, and it is poorly known to what extent bat guano piles are relevant for invertebrate communities in other cave environments and with another set of bat species.

\section{Bats with multiple functions}

Traditionally, bats have been classified according to the principal food item consumed and the general ecomorphological characteristics as an attempt to explain their critical ecosystem roles (Soriano 2000; Aguirre et al. 2003). Nonetheless, the increasing knowledge of bat ecology has shown that, depending on resource availability, physiological constraints, and ecological context, bats can include other food items into their diets, performing ecological roles other than the principal function assigned. For example, some species such as Myotis nigricans Schinz, 1821, and Antrozous pallidus LeConte, 1856, despite being considered as strictly insectivores are found to be potential seed dispersers (Novaes et al. 2015) and pollinators, respectively (Frick et al. 2013). Indeed, it is surprising that $A$. pallidus was more efficient as a pollinator than Leptonycteris yerbabuenae Martínez and Villa-R., 1940, that is assumed to have established a strength mutualism with the columnar cactus Pachycereus pringlei (S. Watson) Britton \& Rose (Frick et al. 2013). Other insectivore-piscivore species such as Noctilio albiventris Desmarest, 1818 include pioneer seeds in their diet during the rainy season in Neotropical savannas, thus having the po- tential to transport and disperse seeds over open areas (Aranguren et al. 2011). These cases along with phytophagous bats that fulfill the double role of seed dispersers and pollinators such as L. curasoae Miller, 1900 (Godínez-Alvarez et al. 2002; Ibarra-Cerdeña et al. 2005), L. yerbabuenae (Rojas-Martínez et al. 2015; Santiago-Hernández et al. 2019), Artibeus watsoni Thomas, 1901 (Tschapka 2003; Melo et al. 2009), and Glossophaga longirostris Miller, 1898 (Nassar et al. 1997; Soriano \& Ruiz 2002) represent other examples of bats with multiple functions.

Many of the aforementioned species are relatively well-studied in terms of their natural history, which suggests how little we know about species' autecology. If novel roles have been found in these common species, to what extent other uncommon species that have rarely been subjected to ecological studies can contribute to multiple functions? I believe that natural history studies can help to enhance our understanding of Neotropical bats not only in their basic biology of species but in their functionality.

\section{Linking with functional traits}

The functional trait-based approach is a reliable framework to address studies that better quantify ecological processes (Luck et al. 2012; Castillo-Figueroa 2018). Since the diversity of functional traits is a key predictor of ecosystem resilience (Núñez et al. 2019), the effect of human-induced habitat modifications on ecological processes can be assessed under this approach (Castillo-Figueroa and Pérez-Torres 2018). Broadly, species contributions to functional roles are categorized by the assignments of functional traits, in which one critical aspect is to know how traits govern the function (Lacher et al. 2019). Even though there is not a formal protocol of functional traits for bats, the use of this approach could be important to establish the linkages between ecosystem functioning and bat traits. For instance, morphological and physiological traits potentially related to ecological functions including gut size, bite force, lingual papillae, gut retention time, among others, may be useful to understand how ecosystem processes are influenced by bat features. This also could explain why some species are involved in multiple ecological roles. I encourage to increase studies that use functional traits when studying ecosystem functions performed by bats. 


\section{Conservation implications}

To conserve bat-mediated ecological processes is urgently needed to mitigate major threats of bats such as logging and harvesting plants, habitat conversion by agriculture, bat persecution, human intrusions, and urban development, just to name a few pressures (Frick et al. 2019; Lacher et al. 2019). However, one of the main concerns regarding bat conservation is the scarcity of information on population status (Frick et al. 2019), which is more challenging in the Neotropics since bat species richness is high but, at the same time, the support for research and conservation planning is limited. Given that several Neotropical plant species depend on bats in different ways either in pollination (Nassar et al. 1997; Valiente-Banuet et al. 2004), seed dispersal (Galindo-González et al. 2000; Vleut et al. 2015), herbivory reduction (Kalka et al. 2008; Williams-Guillén et al. 2009; Morrison \& Lindell 2012) or even in fertilization (Voigt et al. 2015), extirpation of bat species could trigger cascading extinction effects on ecosystem integrity. For example, with population decline or habitat modification that hampers bat movement, seed rain to disturbed areas is precluded, thus reducing soil seed banks and forest regeneration (Cortés-Delgado \& Pérez-Torres, 2011; Lacher et al. 2019). Moreover, considering bats as important mobile links of nutrients (guano), genetic materials (pollen and seeds), and processes (pest control), the impacts on bat species may influence ecosystem resilience (Lundberg \& Morberg 2003), exacerbating the effects on environmental changes in the Neotropics.

\section{Concluding Remarks}

Bats are imperative to ecosystem functioning in the Neotropics. Significant roles in pollination, seed dispersal, arthropod suppression, and nutrient cycling have shown the importance of bats in ecological processes, which has resulted in the increasing studies in the region over the past two decades. Despite this remarkable increase I found, however, the large bias in studies across lowland ecoregions and biomes, highlighting the importance of performing investigations in highland biomes such as Montane Grasslands and Shrublands. There is a need to complement the current scientific evidence with the inclusion of research that assesses other bat and plant species as well as other types of appraisals of the functions such as the trait-based approach. The contribution of bats to ecological processes may depend on resource availabili- ty, physiological constraints, and ecological context, but this has been largely overlooked. It is important to consider that bats can be linked to more than one ecological role. Finally, conservation of New world bats is critical to maintain the functionality of ecosystems but, with the advancing threats that bats are facing combined with the lack of knowledge, profound impacts are expected on Neotropical ecosystems health.

\section{ACKNOWLEDGMENTS}

My gratitude goes to the two anonymous reviewers for insightful comments to the manuscript. I also thank to Laura L. Garzón-Salamanca who substantially improved the quality of the figures.

\section{CORRESPONDING Author}

*dennis.castillof@gmail.com

\section{REFERENCES}

Aguilar-Rodríguez. P.A., MacSwiney, G.M.C., Krömer, T., García-Franco, J.G., Knauer, A. \& Kessler, M. (2014) First record of bat-pollination in the species-rich genus Tillandsia (Bromeliaceae). Ann. Bot., 113, 10471055.

Aguirre, L.F., Herrel, A., Van Damme, R. \& Matthysen, E. (2003) The implications of food hardness for diet in bats. Funct. Ecol., 17, 201-212.

Antonelli, A., Ariza, M., Albert, J., Andermann, T., Azevedo, J., Bacon, C., et al. (2018) Conceptual and empirical advances in Neotropical biodiversity research. PeerJ, DOI:10.7287/peerj.preprints.3074v1.

Aranguren, C.I., González-Carcacía, J.A., Martínez, H. \& Nassar, J.M. (2011) Noctilio albiventris (Noctilionidae), a potential seed disperser in disturbed tropical dry forest habitats. Acta Chiropt., 13, 189-194.

Arroyo-Rodríguez, V., Melo, F.P.L., Martínez-Ramos, M., Bongers, F., Chazdon, R.L., Meave, J.A., et al. (2017) Multiple successional pathways in human-modified tropical landscapes: new insights from forest succession, forest fragmentation and landscape ecology research. Biol. Rev., 92(1), 326-340.

Baldwin, J.W. \& Whitehead, S.R. (2015) Fruit secondary compounds mediate the retention time of seeds in the guts of Neotropical fruit bats. Oecologia, 177, 453-466.

Bernard, E. \& Fenton, M.B. (2003) Bat mobility and roosts in a fragmented landscape in central Amazonia, Brazil. Biotropica, 35, 262-277. 
Boyles, J.G., Cryan, P.M., McCracken, G.F. \& Kunz TH (2011). Economic importance of bats in agriculture. Science, 332, 41-42.

Brown, S. \& Lugo, A.E. (1990) Tropical secondary forests. J. Trop. Ecol., 6, 1-32.

Cadotte, M.W., Carscadden, K. \& Mirotchnick, N. (2011) Beyond species: functional diversity and the maintenance of ecological processes and services. J. Appl. Ecol., 48, 1079-1087.

Castillo-Figueroa, D. (2018) Beyond specimens: linking biological collections, functional ecology and biodiversity conservation. Rev. Peru. Biol., 25(3), 343348.

Castillo-Figueroa, D. \& Pérez-Torres, J. (2018) Respuestas funcionales de murciélagos asociados a fragmentos de bosque seco tropical en Córdoba (Colombia): implicaciones del tipo de manejo en sistemas de ganadería extensiva. Rev. Biodivers. Neotrop., 8(3), 197-211.

Carvalho-Ricardo, M.C., Uieda, W., Fonseca, R.C. \& Rossi, M.N. (2014) Frugivory and the effects of ingestion by bats on the seed germination of three pioneering plants. Acta Oecol., 55, 51-57.

Carvalho, N., Raizer, J. \& Fischer, E. (2017) Passage through Artibeus lituratus (Olfers, 1818) increases germination of Cecropia pachystachya (Urticaceae) seeds. Trop. Conserv. Sci., 10, 1-7.

Cassano, C.R., Silva, R.M., Mariano-neto, E., Schroth, G. \& Faria, D. (2016). Bat and bird exclusion but not shade cover influence arthro- pod abundance and cacao leaf consumption in agroforestry land- scape in northeast Brazil. Agr. Ecosyst. Environ., 232, 247253.

Ceballos, G., Ehrlich, P. \& Dirzo, R. (2017) Biological annihilation via the ongoing sixth mass extinction signaled by vertebrate population losses and declines. Proc. Natl. Acad. Sci., 114(30), E6089-E6096.

Chazdon, R.L., Broadbent, E.N., Rozendaal, D.M.A., Bongers, F., Zambrano, A.M.A., Aide, T.M., et al. (2016) Carbon sequestration potential of second-growth forest regeneration in the Latin American tropics. Sci. Adv., DOI:10.1126/sciadv.1501639

Cleveland, C.J., Betke, M., Federico, P., Frank, J.D., Hallam, T.G., Horn, J. et al. (2006) Economic value of the pest control service provided by Brazilian free-tailed bats in south-central Texas. Front. Ecol. Environ., 4, 238-243.

Córdova-Tapia, F. \& Zambrano, L. (2015) La diversidad funcional en la ecología de comunidades. Ecosistemas, 24, 8-87.
Cortés-Delgado, N. \& Perez-Torres, J. (2011) Habitat edge context and the distribution of phyllostomid bats in the Andean forest and anthropogenic matrix in the Central Andes of Colombia. Biodivers. Conserv., 20, 987-999.

Cole, R.K.J., Holl, K.D. \& Zahawi, R.A. (2010) Seed rain under tree islands planted to restore degraded lands in a tropical agricultural landscape. Ecol. Appl., 20(5), 1255-1269.

Díaz, S. \& Cabido, M. (2001) Vive la différence: plant functional diversity matters to ecosystem processes. Trends Ecol. Evol., 16, 646-655.

Dinerstein, E., Olson, D., Joshi, A., Vynne, C., Burgess, N.D., Wikramanayake, E., et al. (2017) An Ecoregion-Based Approach to Protecting Half the Terrestrial Realm. BioScience, 67, 534-545.

Doughty, C.E., Roman, J., Faurby, S., Wolf, A., Haque, A., Bakker, E.S. et al. (2016) Global nutrient transport in a world of giants. Proc. Natl. Acad. Sci. USA, 113, 868-873.

Duchamp, J.E., Sparks, D.W. \& Swihart, R.K. (2010) Exploring the "nutrient hot spot" hypothesis at trees used by bats. J. Mammal., 91(1), 48-53.

Etter A., McAlpine, C. \& Possingham, H. (2008) A historical analysis of the spatial and temporal drivers of landscape change in Colombia since 1500. Ann. Assoc. Am. Geogr., 98, 1-27.

Emerson, J.K. \& Roark, A.M. (2007) Composition of guano produced by frugivorous, sanguivorous and insectivorous bats. Acta Chiropt., 9, 261-267.

Fleming, T.H., Geiselman, C. \& Kress, W.J. (2009) The evolution of bat pollination: a phylogenetic perspective. Ann. Bot., 104, 1017-1043.

Ferreira, R.L. \& Martins, R.P. (1999) Trophic structure and natural history of bat guano invertebrate communities with special reference to Brazilian caves. Trop. Zool., 12(2), 231-259.

Ferreira, R.L., Prous, X. \& Martins, R.P. (2007) Structure of bat guano communities in a dry Brazilian cave. Trop. Zool., 20(1), 55-74.

Frick, W., Kingston, T. \& Flanders, J. (2019) A review of the major threats and challenges to global bat conservation. Ann. N. Y. Acad. Sci., DOI:10.1111/ nyas. 14045.

Frick, W.F., Price, R.D., Heady, P.A. \& Kay, K.M. (2013) Insectivorous bat pollinates columnar cactus more effectively per visit than specialized nectar bat. Am. Nat., 181, 137-144.

Garbino, G.S., Tavares, V.D.C. (2018) Roosting ecology of Stenodermatinae bats (Phyllostomidae): Evolution 
of foliage roosting and correlated phenotypes. Mammal. Rev., 48, 75-89.

Galindo-González, J., Guevara, S. \& Sosa, V.J. (2000)

Bat and bird-generated seed rains at isolated trees in pastures in a tropical rainforest. Conserv. Biol., 14, 1693-1703.

Geiselman, C.K., Defex, T., Brown, T. \& Younger, S. (2015) Database bat Eco - interactions. Retrieved from http://www.batplant.org/search, Accessed 15 Dec 2019.

Gnaspini, P. \& Trajano, E. (2000) Guano communities in tropical caves. In: H. Wilkens, D.C. Culver \& W.F. Humphreys (Eds.), Ecosystems of the World 30: Subterranean Ecosystems (251-268). Amsterdam: Elsevier.

Godínez-Alvarez, H., Valiente-Banuet, A. \& Rojas-Martínez, A. (2002) The role of seed dispersers in the population dynamics of the columnar cactus Neobuxbaumia tetetzo. Ecology, 83(9), 2617-2629.

González-Maya, J.F., Martínez-Meyer, E., Medellín, R. \& Ceballos, G. (2017) Distribution of mammal functional diversity in the Neotropical realm: Influence of land-use and extinction risk. PLoS ONE, DOI:10.1371/journal.pone.0175931.

Grafe, U.T., Schöner, C.R., Kerth, G., Junaidi, A. \& Schöner, M.G. (2011) A novel resource-service mutualism between bats and pitcher plants. Biol. Lett., 7, 436-439.

Guariguata, M. \& Kattan, G.H. (eds) (2002). Ecología y conservación de bosques neotropicales. San José: Editorial Tecnológica.

Guisande C, Heine J, González-DaCosta J, García-Roselló E (2014) RWizard Software. http://www. 409 ipez.es/ rwizard. Accessed 23 Mar 2020.

Hansen, M.C., Potapov, P.V., Moore, R., Hancher, M., Turubanova, S.A., Tyukavina, A., et al. (2013) High-resolution global maps of 21rst-century forest cover change. Science, 342, 850-853.

Henry, M. \& Joudard, S. (2007) Effect of bat exclusion on patterns of seed rain in tropical rain forest in French Guiana. Biotropica, 39, 510-518.

Ibarra-Cerdeña, C.N., Iñiguez-Dávalos, L.I. \& SánchezCórdero, V. (2005) Pollination ecology of Stenocereus queretaroensis (Cactaceae), a chiropterophilous columnar cactus, in a tropical dry forest of Mexico. Am. J. Bot., 92(3), 503-509.

Johnson, C.N., Balmford, A., Brook, B.W., Buettel, J.C., Galetti, M., Guangchun, L., et al. (2017) Biodiversity losses and conservation responses in the Anthropocene. Science, 356, 270-275.
Karp, D.S. \& Daily, G.C. (2014) Cascading effects of insectivorous birds and bats in tropical coffee plantations. Ecology, 95, 1065-1074.

Kalka, M.B., Smith, A.R. \& Kalko, E.K.V. (2008) Bats limit arthropods and herbivory in a tropical forest. Science, 320, 71.

Kalko, E.K.V., Friemel, D., Handley, Jr. C.O. \& Schnitzler, H.-U. (1999) Roosting andforaging of two neotropical bats, Tonatia silvicola and Trachops cirrhosus (Phyllostomidae). Biotropica, 31, 344-353.

Kalka, M. \& Kalko, E.K.V. (2006) Gleaning bats as underestimated predators of herbivorous insects: diet of Micronycteris microtis (Phyllostomidae) in Panama. J. Trop. Ecol., 22, 1-10.

Kasso, M. \& Balakrishnan, M. (2013) Ecological and Economic Importance of Bats (Order Chiroptera). Hindawi Publishing Corporation, DOI:10.1155/2013/187415.

Kunz, T.H., Braun de Torrez, E., Bauer, D., Lobova, T. \& Fleming, T.H. (2011) Ecosystem services provided by bats. Ann NY Acad Sci, DOI:10.1111/j.17496632.2011.06004.x.

Kunz, T.H., Whitaker, J.O. \& Wadanoli, M.D. (1995) Dietary energetics of the insectivorous Mexican freetailed bat (Tadarida brasiliensis) during pregnancy and lactation. Oecologia, 101, 407-415.

Lacher, T.E., Davidson, A.D., Fleming, T.H., Gómez-Ruiz, E.P., McCracken, G.F., Owen-Smith, N., et al. (2019) The functional roles of mammals in ecosystems. J. Mammal., 100(3), 942-964.

Laurindo, R.D.S., Vizentin-Bugoni, J., Tavares, D.C., Mancini, M.C.S., Mello, R.D.M. \& Gregorin, R. (2020) Drivers of bat roles in Neotropical seed dispersal networks: abundance is more important than functional traits. Oecologia, 193, 189-198.

Librán-Embid, F., De Coster, G. \& Metzger, J.P. (2017) Effects of bird and bat exclusion on coffee pest control at multiple spatial scales. Landsc. Ecol., 32(9), 1907-1920.

Lobova, T.A. \& Mori, S.A. (2004) Epizoochorous dispersal by bats in French Guiana. J. Trop. Ecol., 20, 581-582.

Luck, G., Harrington, R., Harrison, P.A., Kremen, C., Berry, P.M., Bugter, R., et al. (2009) Quantifying the Contribution of Organisms to the Provision of Ecosystem Services. BioScience, 59(3):223-235.

Luck, G., Lavorel, S., McIntyre, S. \& Lumb, K. (2012) Improving the application of vertebrate trait-based frameworks to the study of ecosystem services. J. Anim. Ecol., 81(5), 1065-1076. 
Lundberg, J. \& Moberg, F. (2003) Mobile link organisms and ecosystem functioning: Implications for ecosystem resilience and management. Ecosystems, 6, 87-98.

Maas, B., Karp, D.S., Bumrungsri, S., Kevin Darras, D.G., Huang, J.C.C., Lindell, C.A., et al. (2016) Bird and bat predation services in tropical forests and agroforestry landscapes. Biol. Rev., 91, 1081-1101.

Maas, B., Heath, S., Grass, I., Cassano, C., Classen, A., Faria, D., et al. (2019) Experimental field exclosure of birds and bats in agricultural systems - Methodological insights, potential improvements, and cost-benefit trade-offs. Basic Appl. Ecol., 35, 1-12.

Mammal Diversity Database (2020) American Society of Mammalogists. Retrieved from www.mammaldiversity.org, Accessed 6 March 2020.

Melo, F., Rodriguez-Herrera, B., Chazdon, R.L., Medellin, R.A. \& Ceballos, G.G. (2009) Small tent-roosting bats promote dispersal of large-seeded plants in a Neotropical forest. Biotropica, 41, 737- 743.

Mello, M.A.R., Kalko, E.K.V., Silva, W.R. (2008) Movements of the bat Sturnira lilium and its role as a seed disperser of Solanaceae in the Brazilian Atlantic forest. J. Trop. Ecol., 24, 225-228.

Morrison, E.B. \& Lindell, C.A. (2012) Birds and bats reduce insect biomass and leaf damage in tropical forest restoration sites. Ecol. Appl., 22, 1526-1534.

Muchhala, N. \& Thomson, J.D. (2010) Fur versus feathers: pollen delivery by bats and hummingbirds and consequences for pollen production. Am. Nat., 175, 717-726.

Muscarella, R., \& Fleming, T.H. (2007) The role of frugivorous bats in tropical forest succession. Biol. Rev., 82, 573-590.

Nassar, J.M., Ramírez, M.N. \& Linares, O. (1997) Comparative pollination biology of Venezuelan columnar cacti and the role of nectar-feeding bats in their sexual reproduction. Am. J. Bot., 84, 918-927.

Novaes, R., Souza, R., Ribeiro, E., Siqueira, A., Greco, A. \& Moratelli, R. (2015) First evidence of frugivory in Myotis (Chiroptera, Vespertilionidae, Myotinae). Biodiversity Data Journal, DOI:10.3897/BDJ.3.e6841.

Núñez, S.F., López-Baucells, A., Rocha, R., Farneda, F.Z., Bobrowiec, P.E.D., Palmeirim, J.M., et al. (2019) Echolocation and Stratum Preference: Key Trait Correlates of Vulnerability of Insectivorous Bats to Tropical Forest Fragmentation. Front. Ecol. Evol., DOI: 10.3389/fevo.2019.00373.

Orme, C.D.L., Davies, R.G., Burgess, M., Eigenbrod, F., Pickup, N., Olson, V.A., et al. (2005) Global hotspots of species richness are not congruent with endemism or threat. Nature, 436, 1016-1019.

Oliveira, A.K.M. \& Lemes, F.T.F. (2010) Artibeus planirostris como dispersor e indutor de germinação em uma área do Pantanal do Negro, Mato Grosso do Sul, Brasil. Rev. Bras. Biocienc., 8(1),49-52.

Oliveira, A.K.M., Lemes, F.T.F. \& Pulchério-Leite, A. (2013) Consumo de frutos de Cecropia pachystachya Trécul e Ficus gomelleira Kunt \& C.D. Bouché por Platyrrhinus lineatus (E. Geoffroy, 1810) e seu efeito sobre a germinação de sementes. Rev. Biol. Neotrop., $10(2), 1-8$.

Olson, D.M. \& Dinerstein, E. (2002) The Global 200: Priority ecoregions for global conservation. Ann. Missouri Bot. Gard., 89(2), 199-224.

Olson, D.M., Dinerstein, E., Wikramanayake, E.D., Burgess, N.D., Powell, G.V.N., Underwood, E.C., et al. (2001) Terrestrial ecoregions of the world: A new map of life on Earth. BioScience, 51, 933-938.

Pierson, E.D. (1998) Tall trees, deep holes, and scarred landscapes: conservation biology of North American bats. In: T.H. Kunz, P.A. Racey (Eds.), Bat biology and conservation (309-324). Washington: Smithsonian Institution Press.

Rex, K., Michene, R., Kunz, T.H. \& Voigt, C. (2011) Vertical stratification of Neotropical leaf-nosed bats (Chiroptera: Phyllostomidae) revealed by stable isotopes. J. Trop. Ecol., 27, 211-222.

Renner, S.S. \& Ricklefs, R.E. (1995) Dioecy and its correlates in the flowering plants. Am J Bot, 82, 596-606.

Rojas-Martínez, A.E., Pavón, N.P. \& Castillo, J.P. (2015) Effects of seed ingestion by the lesser long-nosed bat Leptonycteris yerbabuenae on the germination of the giant cactus Isolatocereus dumortieri. Southwest. Nat., 60(1), 85-89.

Rull, V. \& Carnavli, A.C. (2020) Neotropical diversification: Patterns and Processes. Cham: Springer.

Saldaña-Vázquez, R.A., Castaño, J.H., Baldwin, J. \& Pérez-Torres, J. (2019) Does seed ingestion by bats increase germination?: a new meta-analysis 15 years later. Mammal. Rev., 49, 201-209.

Salgado, S.S., Motta, P.C., De Souza Aguiar, L.M. \& Nardoto, G.B. (2014) Tracking dietary habits of cave arthropods associated with deposits of hematophagous bat guano: A study from a neotropical savanna. Austral. Ecol., 39, 560-566.

Sampedro, A.C., Martínez, C.M., Mercado, A.M., Osorio, S.C., Oteroy, Y.L. \& Santos, L.M. (2008) Refugios, período reproductivo y composición social de las poblaciones de Desmodus rotundus (Geoffroy, 1810) 
(Chiroptera: Phyllostomidae), en Zonas Rurales del Departamento de Sucre, Colombia. Caldasia, 30, 127-134.

Santiago-Hernández, M.H., Martén-Rodríguez, S., Lopezaraiza-Mikel, M., Oyama, K., González-Rodríguez, A. \& Quesada, M. (2019) The role of pollination effectiveness on the attributes of interaction networks: from floral visitation to plant fitness. Ecology. DOI:10.1002/ecy.2803.

Soriano, P. (2000) Functional structure of bat communities in tropical rainforests and Andean cloud forests. Ecotropicos, 13, 1-20.

Soriano, P.J. \& Ruiz, A. (2002) The Role of Bats in Reproduction of Columnar Cacti in the Northern Andes. In: T.H. Fleming A. \& Valiente-Banuet (Eds.), Ecology, Evolution and Conservation of columnar cacti and their mutualists (241-263). Tucson: Arizona University Press.

Tremlett, C.J., Moore, M., Chapman, M.A., Zamora-Gutierrez, V. \& Peh, K.S.H. (2019) Pollination by bats enhances both quality and yield of a major cash crop in Mexico. J. Appl. Ecol., 57(3), 450-459.

Tschapka, M. (2003) Pollination of the understorey palm Calyptrogyne ghiesbreghtiana by hovering and perching bats. Biol. J. Linn. Soc., 80, 281-288.

Valiente-Banuet, A., Molina-Freaner, F., Torres, A., Arizmendi, M.C. \& Casas, A. (2004) Geographic dif- ferentiation in the pollination system of the columnar cactus Pachycereus pecten-aboriginum. Am. J. Bot., 91, 850-855.

Valiente-Banuet, A., Arizmendi, A.M., Rojas-Martínez, A. \& Domínguez-Canseco, I. (1996) Ecological relationships between columnar cacti and nectar feeding bats in Mexico. J. Trop. Ecol., 12, 103-119.

Villalobos-Chaves, D., Melo, F.P.L. \& Rodríguez-Herrera, B. (2020) Dispersal patterns of large-seeded plants and the foraging behavior of a frugivorous bat. J. Trop. Ecol., DOI: 10.1017/S0266467420000036.

Vitousek, P.M. \& Howarth, R.W. (1991) Nitrogen limitation on land and in the sea: how can it occur? Biogeochemistry, 13, 87-115.

Vleut, I., Levy-Tacher, S.I., Galindo-González, J. \& de Boer, W.F. (2015). Positive effect of surrounding rainforest on composition, diversity and late-successional seed dispersal by bats. Basic. Appl. Ecol., 16, 308-315.

Voigt, C., Borissov, I. \& Kelm, D.H. (2015). Bats Fertilize Roost Trees. Biotropica, 47(4), 403-406.

Williams-Guillén, K., Perfecto, I. \& Vandermeer, J. (2008) Bats limit insects in a neotropical agroforestry system. Science, 320, 70. 


\section{SUPPLEMENTARY MATERIAL}

Fig. S1. Procedure for selecting studies in the systematic review of bat-mediated ecological processes in the Neotropics.



Table S1. List of references used in the systematic review.

1. Aguilar-Garavito, M., Renjifo, L.M. \& Pérez-Torres, J. (2014) Seed dispersal by bats across four successional stages of a subandean landscape. Biota. Colomb., 15(2), 87-101.

2. Aguilar-Rodríguez, P.A., Krömer, T., García-Franco, J.G., Escobedo-Sarti, J., \& MacSwiney, G.M.C. (2019) Bat pollination in the Bromeliaceae. Plant Ecol. Divers., DOI:10.1080/17550874.2019.1566409.

3. Aguilar-Rodríguez, P.A., Krömer, T., García-Franco, J.G. \& MacSwiney, M.C. (2015) From dusk till dawn: nocturnal and diurnal pollination in the epiphyte Tillandsia heterophylla (Bromeliaceae). Plant Biol., 18(1), 37-45.

4. Aguilar-Rodríguez, P.A., Tschapka, M., García-Franco, J.G., Krömer, T. \& MacSwiney, M.C. (2019) Bromeliads going batty: pollinator partitioning among sympatric chiropterophilous Bromeliaceae. AoB Plants, DOI:10.1093/aobpla/plz014.

5. Aguilar-Rodríguez, P.A., MacSwiney, G.M.C., Krömer, T., García-Franco, J.G., Knauer, A. \& Kessler, M. (2014) First record of bat-pollination in the species-rich genus Tillandsia (Bromeliaceae). Ann. Bot., 113, 1047-1055.

6. Aguirre, G., Arteaga, L.L. \& Moya, M.I. (2006) Proporción y velocidad de germinación de semillas de Vismia glaziovii (Guttifferae) obtenidas de las heces de murciélagos frugívoros. Rev. Bol. Ecol., 19, 101106.

7. Alcorn, S.M., McGregor, S.E., \& Olin G (1961) Pollination of Saguaro Cactus by Doves, Nectar-Feeding Bats, and Honey Bees. Science, 133, 1594-1595.

8. Aranguren, C.I., González-Carcacía, J.A., Martínez, H. \& Nassar, J.M. (2011) Noctilio albiventris (Noctilionidae), a potential seed disperser in disturbed tropical dry forest habitats. Acta Chiropt., 13, 189-194.

9. Arias-Coyotl, E., Stoner, K.E. \& Casas, A. (2006) Effectiveness of bats as pollinators of Stenocereus stellatus (Cactaceae) in wild, managed in situ, and cultivated populations in la Mixteca baja, Central Mexico. Am. J. Bot., 93(11), 1675-1683.

10. Arteaga, L.L., Aguirre, L.F. \& Moya, M.I. (2006) Seed Rain Produced by Bats and Birds in Forest Islands in a Neotropical Savanna. Biotropica, 38(6), 718-724. 
11. Arziaga, S., Ezcurra, E., Petters, E., Ramírez de Arellano, F. \& Vega, F. (2000) Pollination ecology of Agave macroacantha (Agavaceae) in a Mexican Tropical Desert. II. The role of pollinators. Am. J. Bot., 87(7), 1011-1017.

12. Bahia, G.R. \& Ferreira, R.L. (2005) Influência das características físicoquímicas e da matéria orgânica de depósitos recentes de guano de morcego na riqueza e diversidade de invertebrados de uma caverna calcária. Rev. Bras. Zoociencias, 7(1), 165-180.

13. Baldwin, J.W. \& Whitehead, S.R. (2015) Fruit secondary compounds mediate the retention time of seeds in the guts of Neotropical fruit bats. Oecologia, 177, 453-466.

14. Banck, S.A., Horn, M.H. \& Gawlicka, A. (2002) Disperser- vs. Establishment-Limited Distribution of a Riparian Fig Tree (Ficus insipida) in a Costa Rican Tropical Rain Forest. Biotropica, 34(2), 232-243.

15. Bianconi, G.V., Mikich, S.B.B., Teixeira, S.D. \& Maia, B.H. (2007) Attraction of fruit eating bats with essential oils of fruits: a potential tool for forest restoration. Biotropica, 39, 136-140.

16. Bianconi, G.V., Urubatan, M.S., Cruz-Neto, A.P. \& Mikich, S.B. (2012) Use of fruit essential oils to assist forest regeneration by bats. Restor. Ecol., 20, 211-217.

17. Bizerril, M.X.A. \& Raw, A. (1998) Feeding Behaviour of Bats and the Dispersal of Piper arboreum Seeds in Brazil. J. Trop. Ecol., 14(1), 109-114.

18. Boyles, J.G., Cryan, P.M., McCracken, G.F. \& Kunz, T.H. (2011) Economic importance of bats in agriculture. Science, 332, 41-42.

19. Boyles, J.G., Sole, C.L., Cryan, P.M. \& McCracken, G.F. (2013) On estimating the economic value of insectivorous bats: prospects and priorities for biologists. In: R. Adams \& S.C. Pedersen (Eds.), Bat Evolution, Ecology, and Conservation (501-515). New York: Springer.

20. Bustamante, E., Casas, A. \& Búrquez, A. (2010) Geographic variation in reproductive success of Stenocereus thurberi (cactaceae): effects of pollination timing and pollinator guild. Am. J. Bot., 97(12), 2020-2030.

21. Carvalho, N., Raizer, J. \& Fischer, E. (2017) Germination of Cecropia pachystachya (Urticaceae) Dispersed by Artibeus lituratus (Olfers, 1818) and Artibeus planirostris (Spix, 1823; Chiroptera, Phyllostomidae), Campo Grande, Mato Grosso do Sul, Brazil. Trop. Conserv. Sci., 10, 1-8.

22. Carvalho, N., Raizer, J. \& Fischer, E. (2017) Passage through Artibeus lituratus (Olfers, 1818) increases germination of Cecropia pachystachya (Urticaceae) seeds. Trop. Conserv. Sci., 10, 1-7.

23. Carvalho-Ricardo, M.C., Uieda, W., Fonseca, R.C. \& Rossi, M.N. (2014) Frugivory and the effects of ingestion by bats on the seed germination of three pioneering plants. Acta Oecol., 55, 51-57.

24. Casallas-Pabón, D., Calvo-Roa, N. \& Rojas-Robles, R. (2017) Murciélagos dispersores de semillas en gradientes sucesionales de la Orinoquia (San Martín, Meta, Colombia). Acta Biol. Colomb., 22(3), 348358.

25. Casas, A., Valiente-Banuet, A., Rojas-Martínez, A. \& Dávila, P. (1999) Reproductive biology and the process of domestication of the columnar cactus Stenocereus stellatus in central Mexico. Am. J. Bot., 86(4), 534-542.

26. Cascante-Marín, A., Oostermeijer, J.G.B., Wolf, J.H.D. \& Nijs, C.M. (2005) Reproductive Biology of the Epiphytic Bromeliad Werauhia gladiolifrlora in a Premontane Tropical Forest. Plant Biol., 7, 203-209.

27. Cassano, C.R., Silva, R.M., Mariano-neto, E., Schroth, G. \& Faria, D. (2016). Bat and bird exclusion but not shade cover influence arthro- pod abundance and cacao leaf consumption in agroforestry landscape in northeast Brazil. Agr. Ecosyst. Environ., 232, 247-253.

28. Castro-Luna, A.A. \& Galindo-González, J.G. (2012) Seed Dispersal by Phyllostomid Bats in Two Contrasting Vegetation Types in a Mesoamerican Reserve. Acta Chiropt., 14(1), 133-142.

29. Castro-Luna, A.A. \& Sosa, V.J. (2009) Consumption of Conostegia xalapensis fruits and seed dispersal of Coussapoa oligocephala by the nectarivorous bat Hylonycteris underwoodi Thomas, 1903 (Chiroptera: Phyllostomidae). Stud. Neotrop. Fauna Environ., 44, 137-139.

30. Charles-Dominique, P. (1986) Inter-relations between frugivorous vertebrates and pioneer plants: Cecropia, birds and bats in French Guyana. In: A. Estrada \& T.H. Fleming (Eds.), Frugivores and seed dispersal (119-135). Dordrecht: Springer.

31. Charles-Dominique, P. \& Cockle, A. (2001) Frugivory and Seed Dispersal by Bats. In: F. Bongers, P. Charles-Dominique, P.M. Forget \& M. Théry (Eds.), Nouragues. Monographiae Biologicae (207-216). Dordrecht: Springer.

32. Christianini, A.V., Forzza, R.C. \& Buzato, S. (2012) Divergence on floral traits and vertebrate pollinators of two endemic Encholirium bromeliads. Plant Biol., 15(2), 360-368. 
33. Cleveland, C.J., Betke, M., Federico, P., Frank, J.D., Hallam, T.G., Horn, J., et al. (2006) Economic value of the pest control service provided by Brazilian free-tailed bats in south-central Texas. Front. Ecol. Environ., 4, 238-243.

34. Cole, R.K.J., Holl, K.D. \& Zahawi, R.A. (2010) Seed rain under tree islands planted to restore degraded lands in a tropical agricultural landscape. Ecol. Appl., 20(5), 1255-1269.

35. Cunningham, S.A. (1995) Ecological Constraints on Fruit Initiation by Calyptrogyne ghiesberghtiana (Arecaceae): Floral Herbivory, Pollen Availability, and Visitation by Pollinating Bats. Am. J. Bot., 82(12), 1527-1536.

36. Cunningham, S.A. (1996) Pollen Supply Limits Fruit Initiation by a Rain Forest Understorey Palm. J. Ecol., 84(2), 185-194.

37. Dar, S., del Coro-Arizmendi, M. \& Valiente-Banuet, A. (2006) Diurnal and Nocturnal Pollination of Marginatocereus marginatus (Pachycereeae: Cactaceae) in Central Mexico. Ann. Bot., 97, 423-427.

38. Diniz, U.M., Domingos-Melo, A. \& Machado, I.C. (2019) Flowers up! The effect of floral height along the shoot axis on the fitness of bat pollinated species. Ann. Bot., DOI: 10.1093/aob/mcz116.

39. Diniz, U.M., Lima, S.A. \& Machado, I.C.S. (2019) Short-distance pollen dispersal by bats in an urban setting: monitoring the movement of a vertebrate pollinator through fluorescent dyes. Urban Ecosyst., 22, 281-291.

40. Dos Reis, R. \& Guillaumet, J.L. (1983) Les chauvessouris frugivores de la région de Manaus et leur rôle dans la dissémination des espèces végétales. Rev. Ecol. (Tierre Vie), 38(2), 147-169.

41. Emerson, J. \& Droak, A. (2007) Composition of guano produced by frugivorous, sanguivorous, and insectivorous bats. Acta Chiropt., 9(1), 261-267.

42. Estrada-Villegas, S., Pérez-Torres, J., Stevenson, P.R. (2007) Dispersión de semillas por murciélagos en un borde de bosque montano. Ecotrópicos, 20, 1-14.

43. Federico, P., Hallam, T.G., McCracken, G.F., Purucker, S.T., Grant, W.E., Correa-Sandoval, A.N., et al. (2008) Brazilian free-tailed bats as insect pest regulators in transgenic and conventional cotton crops. Ecol. Appl., 18, 826-837.

44. Ferreira, R.L. \& Martin, R.P. (1998) Diversity and Distribution of Spiders Associated with Bat Guano Piles in Morrinho Cave (Bahia State, Brazil). Divers. Distrib., 4(5/6), 235-241.
45. Ferreira, R.L. \& Martins, R.P. (1999) Trophic structure and natural history of bat guano invertebrate communities with special reference to Brazilian caves. Trop. Zool., 12(2), 231-259.

46. Ferreira, R.L. \& Martins, R.P (2009) Mapping subterranean resources: The cave invertebrates distribution as indicator of food availability. Rev. Bras. Zool., 11(2), 119-127.

47. Ferreira, R.L., Prous, X. \& Martins, R.P. (2007) Structure of bat guano communities in a dry Brazilian cave. Trop. Zool., 20(1), 55-74.

48. Figueiredo, R.A. \& Perin, E. (1995) Germination ecology of Ficus luschnathiana drupelets after bird and bat ingestion. Acta Oecol., 16, 71-75.

49. Fleming, T.H. (1981) Fecundity, Fruiting Pattern, and Seed Dispersal in Piper Amalago (Piperaceae), a Bat-Dispersed Tropical Shrub. Oecologia, 51, 42-46.

50. Fleming, T.H., Heithaus, E.R. (1981) Frugivorous bats, seed shadows, and the structure of tropical forests. Biotropica, 13, 45-53.

51. Fleming, T.H. \& Sosa, V.J. (1994) Effects of Nectarivorous and Frugivorous Mammals on Reproductive Success of Plants. J. Mammal., 75(4), 845-851.

52. Fleming, T.H., Merlin, D. \& Horner, M.A. (1996) Pollination Biology and the Relative Importance of Nocturnal and Diurnal Pollinators in Three Species of Sonoran Desert Columnar Cacti. Southwest. Nat., 41(3), 257-269.

53. Fleming, T.H., Sahley, C.T., Holland, J.N., Nason, J.D. \& Hamrick, J.L. (2001) Sonoran Desert columnar cacti and the evolution of generalized pollination systems. Ecol. Monogr., 71, 511-530.

54. Fleming, T.H. \& Muchhala, N. (2008) Nectar-feeding bird and bat niches in two worlds: pantropical comparisons of vertebrate pollination systems. J. Biogeogr., 35, 764-780.

55. Fleming, T.H., Geiselman, C. \& Kress, W.J. (2009) The evolution of bat pollination: a phylogenetic perspective. Ann. Bot., 104, 1017-1043.

56. Foster, R.B., Arce, J. \& Watcher, T. (1986) Guano communities in tropical caves. In: A. Estrada \& T.H. Fleming (Eds.), Frugivores and seed dispersal (357370). Dordrecht: Springer.

57. Frick, W.F., Price, R.D., Heady, P.A. \& Kay, K.M. (2013) Insectivorous bat pollinates columnar cactus more effectively per visit than specialized nectar bat. Am. Nat., 181, 137-144.

58. Galindo-González, J. (1998) Dispersión de semillas por murcielagos: su importancia en la conservación 
y regeneración del bosque tropical. Acta Zool. Mex. (ns), 73, 57-74.

59. Galindo-González, J., Guevara, S. \& Sosa, V.J. (2000) Bat and bird-generated seed rains at isolated trees in pastures in a tropical rainforest. Conserv. Biol., 14, 1693-1703.

60. Galindo-González, J., Vázquez-Domínguez, G., Saldaña-Vázquez, R.A. \& Hernández-Montero, J.R. (2009) A more efficient technique to collect seeds dispersed by bats. J. Trop. Ecol., 25(2), 205-209.

61. García, Q.S., Rezende, J.L.P. \& Aguiar, L.M.S. (2000) Seed dispersal by bats in a disturbed area of Southeastern Brazil. Rev. Biol. Trop., 48(1), 125-128.

62. García-Morales, R., Chapa-Vargas, L., Galindo-González, J. \& Badano, E.I. (2012) Seed dispersal among three different vegetation communities in the Huasteca region, Mexico, analyzed from bat feces. Acta Chiropt., 14(2), 357-367.

63. Gnaspini, P. \& Trajano, E. (2000) Guano communities in tropical caves. In: H. Wilkens, D.C. Culver, W.F. \& Humphreys (Eds.)., Ecosystems of the World 30: Subterranean Ecosystems (251-268). Amsterdam: Elsevier.

64. Godínez-Alvarez, H. \& Valiente-Banuet, A. (1998) Germination and early seedling growth of Tehuacán Valley cacti species: the role of seed ingestion by dispersers and soils on seedling growth. J. Arid. Environ., 39, 21-31.

65. Godínez-Alvarez, H. \& Valiente-Banuet, A. (2000) Fruit-Feeding Behavior of the Bats Leptonycteris curasoae and Choeronycteris mexicana in Flight Cage Experiments: Consequences for Dispersal of Columnar Cactus Seeds. Biotropica, 32(3), 552-556.

66. Godínez-Alvarez, H., Valiente-Banuet, A. \& Rojas-Martínez, A. (2002) The role of seed dispersers in the population dynamics of the columnar cactus Neobuxbaumia tetetzo. Ecology, 83(9), 2617-2629.

67. Gomes, F.T.M.C., Ferreira, F.L. \& Jacobi, C.M. (2000) Comunidade de artrópodes de uma caverna calcária em área de mineração: composição e estructura. Rev. Bras. Zoociencias, 2(1), 77-96.

68. Gorchov, D.L., Cornejo, F. \& Ascorra, C., Jaramillo, M. (1993). The role of seed dispersal in the natural regeneration of rainforest after strip-cutting in the Peruvian Amazon. Vegetatio, DOI:107/108:339-349.

69. Gribel, R. \& Gibbs, P.E. (2002) High outbreeding as a consequence of selfed ovule mortality and single vector bat pollination in the Amazonian tree Pseudobombax munguba (Bombacaceae). Int. J. Plant. Sci., 163(6), 1035-1043.
70. Heer, K., Albrecht, L. \& Kalko, E.K.V. (2010) Effects of ingestion of neotropical bats on germination parameters of native free-standing and strangler figs (Ficus sp., Moraceae). Oecologia, 163, 425-435.

71. Heithaus, E.R., Opler, P.A. \& Baker, H.G. (1974) Bat Activity and Pollination of Bauhinia Pauletia: Plant-Pollinator Coevolution. Ecology, 55(2), 412419.

72. Heithaus, E.R. \& Fleming, T.H. (1978) Foraging Movements of a Frugivorous Bat, Carollia perspicillata (Phyllostomatidae). Ecol. Monogr., 48(2),127143.

73. Heithaus, E.R., Stashko, E. \& Anderson, P.K. (1982) Cumulative Effects of Plant-Animal Interactions on Seed Production by Bauhinia Ungulata. Ecology, 63(5), 1294-1302.

74. Henry, M. \& Joudard, S. (2007) Effect of bat exclusion on patterns of seed rain in tropical rain forest in French Guiana. Biotropica, 39, 510-518.

75. Hernández-Montero, J.R., Rojas-Soto, O.R. \& Saldaña-Vázquez, R.A. (2011) Consumo y dispersión de semillas de Solanum schlechtendalianum (Solanaceae) por el murciélago frugívoro Sturnira ludovici (Phyllostomidae). Chiropt. Neotrop., 17(2), 10171021.

76. Herrerías-Diego, Y., Quesada, M., Stoner, K.E. \& Lobo, J. (2006) Effects of Forest Fragmentation on Phenological Patterns and Reproductive Success of the Tropical Dry Forest Tree Ceiba aesculifolia. Conserv. Biol., 20(4), 1111-1120.

77. Howell, D.J. \& Roth, B. (1981) Sexual Reproduction in Agaves: The Benefits of Bats; The Cost of Semelparous Advertising. Ecology, 62(1), 1-7.

78. Ibarra-Cerdeña, C.N., Iñiguez-Dávalos, L.I. \& Sánchez-Córdero, V. (2005) Pollination ecology of Stenocereus queretaroensis (cactaceae), a chiropterophilous columnar cactus, in a tropical dry forest of Mexico. Am. J. Bot., 92(3), 503-509.

79. Iudica, C.A. \& Bonaccorso, F.J. (1997) Feeding of the Bat, Sturnira lilium, on Fruits of Solanum riparium Influences Dispersal of this Pioneer Tree in Forests of Northwestern Argentina. Stud. Neotrop. Fauna Environ., 32, 4-6.

80. Jacomassa, F.A.F. \& Pizo, M.A. (2010) Birds and bats diverge in the qualitative and quantitative components of seed dispersal of a pioneer tree. Acta Oecol., 36, 493-496.

81. Janzen, D.H., Miller, G.A., Hackforth-Jones, J., Pond, C.M., Hooper, K. \& Janos, D.P. (1976). Two Costa 
Rican Bat-Generated Seed Shadows of Anidra inermis (Leguminosae). Ecology, 57(5), 1068-1075.

82. Janzen, D.H. (1978) A Bat-Generated Fig Seed Shadow in Rainforest. Biotropica, 19(2), 121.

83. Kalka, M. \& Kalko, E.K.V (2006) Gleaning bats as underestimated predators of herbivorous insects: diet of Micronycteris microtis (Phyllostomidae) in Panama. J. Trop. Ecol., 22, 1-10.

84. Kalka, M.B., Smith, A.R. \& Kalko, E.K.V. (2008) Bats limit arthropods and herbivory in a tropical forest. Science, 320, 71.

85. Karp, D.S. \& Daily, G.C. (2014) Cascading effects of insectivorous birds and bats in tropical coffee plantations. Ecology, 95, 1065-1074.

86. Kasso, M. \& Balakrishnan, M. (2013) Ecological and Economic Importance of Bats (Order Chiroptera). Hindawi Publishing Corporation, DOI:10.1155/2013/187415.

87. Kelm, D.H., Wiesner, K.R. \& von Helversen, O. (2008) Effects of artificial roosts for frugivorous bats on seed dispersal in a Neotropical forest pasture mosaic. Conserv. Biol., 22, 733-741.

88. Kress, J. \& Stone, D.E. (1993) Morphology and Floral Biology of Phenakospermum (Strelitziaceae), an Arborescent Herb of the Neotropics. Biotropica, 25(3), 290-300.

89. Kunz, T.H., Braun de Torrez, E., Bauer, D., Lobova, T. \& Fleming, T.H. (2011) Ecosystem services provided by bats. Ann. NY Acad. Sci., DOI:10.1111/j.17496632.2011.06004.x.

90. Lacher, T.E., Davidson, A.D., Fleming, T.H., Gómez-Ruiz, E.P., McCracken, G.F., Owen-Smith, N., Peres, C. \& Vander Wall, S.B. (2019) The functional roles of mammals in ecosystems. J. Mammal., 100(3), 942-964.

91. Lagomarsino, L.P. \& Muchhala, N. (2019) A gradient of pollination specialization in three species of Bolivian Centropogon. Am. J. Bot., 106(5), 633-642.

92. Librán-Embid, F., De Coster, G. \& Metzger, J.P. (2017). Effects of bird and bat exclusion on coffee pest control at multiple spatial scales. Landsc. Ecol., 32(9), 1907-1920.

93. Lindner, A. \& Morawetz, W. (2006) Seed dispersal by frugivorous bats on landslides in a montane rain forest in Southern Ecuador. Chiropt. Neotrop., 12(1), 232-237.

94. Loayza, A.P., Rios, R.S. \& Larrea-Alcázar, D.M. (2006) Disponibilidad de recurso y dieta de murciélagos frugívoros en la Estación Biológica Tunquini, Bolivia. Ecología en Bolivia, 41(1), 7-23.
95. Lobo, J.A., Quesada, M. \& Stoner, K.E. (2005) Effects of pollination by bats on the mating system of Ceiba pentandra (Bombacaceae) populations in two tropical life zones in Costa Rica. Am. J. Bot., 92(2), 370-376.

96. Lobova, T.A., Mori, S.A., Blanchard, F., Peckham, H. \& Charles-Dominique, P. (2003) Cecropia as a food resource for bats in French Guiana and the significance of fruit structure in seed dispersal and longevity. Am. J. Bot., 90, 388-404

97. Lobova, T.A. \& Mori, S.A. (2004) Epizoochorous dispersal by bats in French Guiana. J. Trop. Ecol., 20, 581-582.

98. Lopez, J.E. \& Vaughan, C. (2004) Observations on the role of frugivorous bats as seed dispersers in Costa Rican secondary humid forests. Acta Chiropt., 6, 111-119.

99. Maas, B., Karp, D.S., Bumrungsri, S., Kevin Darras, D.G., Huang, J.C.C., Lindell, C.A., et al. (2016) Bird and bat predation services in tropical forests and agroforestry landscapes. Biol. Rev., 91, 1081-1101.

100.Marques, M.C.M. \& Fischer, E. (2009) Effect of bats on see d distribution and germination of Calophyllum brasiliense (Clusiaceae). Ecotropica, 15, 1-6.

101.Marques, J.S., Tagliati, M.C. \& Faria, A.P. (2015) Diurnal versus nocturnal pollination success in Billbergia horrida Regel (Bromeliaceae) and the first record of chiropterophily for the genus. An. Acad. Bras. Ciênc., 87(2), 835-842.

102.Martínez-Garza, C. \& González-Montagut, R. (2002) Seed rain of fleshy-fruited species in tropical pastures in Los Tuxtlas, Mexico. J. Trop. Ecol., 18, 457-462.

103.McCracken, G.F., Westbrook, J.K., Brown, V.A., Eldridge, M., Federico P. \& Kunz, T.H. (2012) Bats track and exploit changes in insect pest populations. PLoS One, DOI: 10.1371/journal.pone.0043839.

104.McGregor, S.E., Alcorn, S.M. \& Olin, G. (1962) Pollination and Pollinating Agents of the Saguaro. Ecology, 43(2), 259-267.

105.Medellín, R.A. \& Gaona, O. (1999). Seed dispersal by bats and birds in forest and disturbed habitats of Chiapas, Mexico. Biotropica, 31, 478-485.

106.Mello, M.A.R., Kalko, E.K.V. \& Silva, W.R. (2008) Movements of the bat Sturnira lilium and its role as a seed disperser of Solanaceae in the Brazilian Atlantic forest. J. Trop. Ecol., 24, 225-228.

107.Melo, F., Rodriguez-Herrera, B., Chazdon, R.L., Medellin, R.A. \& Ceballos, G.G. (2009) Small tent-roosting bats promote dispersal of large-seeded plants in a Neotropical forest. Biotropica, 41, 737-743. 
108.Molina-Freaner, F., Eguiarte, L.E. (2003). The pollination biology of two paniculate agaves (Agavaceae) from northwestern Mexico: contrasting roles of bats as pollinators. Am. J. Bot., 90(7), 1016-1024.

109. Molina-Freaner, F., Rojas-Martínez, A., Fleming, T.H. \& Valiente-Banuet, A. (2004) Pollination biology of the columnar cactus Pachycereus pecten-aboriginum in north-western México. J. Arid. Environ., $56,117-127$.

110. Moreira-Hernández, J.I., Terzich, N., Zambrano-Ceballos, R., Oleas, N.H. \& Muchhala, N. (2019) Differential tolerance to increasing heterospecific pollen deposition in two sympatric species of Burmeistera (Campanulaceae: Lobelioideae). Int. J. Plant. Sci., 180(9), 987-995.

111. Morrison, E.B. \& Lindell, C.A. (2012) Birds and bats reduce insect biomass and leaf damage in tropical forest restoration sites. Ecol. Appl., 22, 1526-1534.

112. Muchhala, N. (2003) Exploring the boundary between pollination syndromes: bats and hummingbirds as pollinators of Burmeistera cyclostigmata and B. tenuiflora (Campanulaceae). Oecologia, 134, 373-380.

113. Muchhala, N. (2006) The pollination biology of Burmeistera (Campanulaceae): specialization and syndromes. Am. J. Bot., 93(8), 1081-1089.

114. Muchhala ,N. (2007) Adaptive Trade-Off in Floral Morphology Mediates Specialization for Flowers Pollinated by Bats and Hummingbirds. Am. Nat., 169(4), 494-504.

115. Muchhala, N., Caiza, A., Vizuete. J.C. \& Thomson, J.D. (2008) A generalized pollination system in the tropics: bats, birds and Aphelandra acanthus. Ann. Bot., 103, 1481-1487.

116. Muchhala, N. \& Thomson, J.D. (2010) Fur versus feathers: pollen delivery by bats and hummingbirds and consequences for pollen production. Am. Nat. 175, 717-726.

117. Muchhala, N. \& Thomson, J.D. (2012) Interspecific competition in pollination systems: costs to male fitness via pollen misplacement. Funct. Ecol., 26(2), 476-482.

118. Munguía-Rosas, M.A., Sosa, V.J. \& Jácome-Flores, M.E. (2010) Pollination system of the Pilosocereus leucocephalus columnar cactus (tribe Cereeae) in eastern Mexico. Plant Biol., 12, 578-586.

119. Munin, R.L., da Costa, P.C. \& Fischer, E. (2011) Differential ingestion of fig seeds by a Neotropical bat, Platyrrhinus lineatus. Mammal. Biol., 76, 772-774.
120.Muscarella, R. \& Fleming TH (2007) The role of frugivorous bats in tropical forest succession. Biol. Rev., 82, 573-590.

121.Naranjo, M.E., Renjifo, C. \& Soriano, P.J. (2003) Effect of Ingestion by Bats and Birds on Seed Germination of Stenocereus griseus and Subpilocereus repandus (Cactaceae). J. Trop. Ecol., 19(1), 19-25.

122.Nassar, J.M., Ramírez, M.N. \& Linares, O. (1997) Comparative pollination biology of Venezuelan columnar cacti and the role of nectar-feeding bats in their sexual reproduction. Am. J. Bot., 84, 918-927.

123. Novaes, R., Souza, R., Ribeiro, E., Siqueira, A., Greco, A. \& Moratelli, R. (2015) First evidence of frugivory in Myotis (Chiroptera, Vespertilionidae, Myotinae). Biodivers Data J, 3:e6841 DOI: 10.3897/ BDJ.3.e6841.

124. Novoa, S., Cadenillas, R. \& Pacheco, V. (2011). Dispersión de semillas por murciélagos frugívoros en bosques del Parque Nacional Cerros de Amotape, Tumbes, Perú. Mastozol. Neotrop., 18(1), 81-93.

125.Oliveira, A.K. \& Lemes, F.T. (2010) Artibeus planirostris como dispersor e indutor de germinação em uma área do Pantanal do Negro, Mato Grosso do Sul, Brasil. Rev. Bra. Bioci., 8(1), 49-52.

126. Oliveira, A.K.M., Lemes, F.T.F. \& Pulchério-Leite, A. (2013) Consumo de frutos de Cecropia pachystachya Trécul e Ficus gomelleira Kunt \& C.D. Bouché por Platyrrhinus lineatus (E. Geoffroy, 1810) e seu efeito sobre a germinação de sementes. Rev. Biol. Neotrop., 10(2), 1-8.

127.Oliveira, A.K.M., Lemes, F.T.F. \& Pulchério-Leite, A. (2018) Are the germination and vigor of Ficus and Cecropia seeds affected by the digestion process of a frugivorous bat? Neotrop. Biol. Conserv., 13(1), 2-9.

128.Palmerin, J.M., Gorchov, D.L. \& Stoleson, S. (1989) Trophic structure of a neotropical frugivore community: is there competition between birds and bats? Oecologia, 79, 403-411.

129.Passos, J.G. \& Passamani, M. (2003) Artibeus lituratus (Chiroptera, Phyllostomidae): biologia e dispersão de sementes no Parque do Museu de Biologia Prof. Mello Leitão, Santa Teresa (ES). Natureza on line, $1(1), 1-6$.

130.de la Peña-Domene, M., Martínez-Garza, C., Palmas-Pérez, S., Rivas-Alonso, E. \& Howe, H.F. (2014) Roles of Birds and Bats in Early Tropical Forest Restoration. PLoS ONE, DOI:10.1371./journal. pone. 0104656 . 
131.Peitt, S. (1995) The pollinators of two species of columnar cacti in Curacao, Netherlands Antilles. Biotropica, 27, 538-541.

132.Preciado-Benítez, O., Gómez y Gómez, B.B., Navarrete Gutiérrez, D.A. \& Horváth, A. (2015) The use of commercial fruits as attraction agents may increase the seed dispersal by bats to degraded areas in Southern Mexico. Trop. Conserv. Sci., 8(2), 301-317.

133. Queiroz, J.A., Quirino, Z.G.M., Lopes, A.V. \& Machado IC (2016) Vertebrate mixed pollination system in Encholirium spectabile: a bromeliad pollinated by bats, opossum and hummingbirds in a tropical dry forest. J. Arid. Environ., 125, 21-30.

134. Quesada, M., Rosas-Guerrero, V., Palacios-Guevara, C. \& Lobo, J.A. (2003) Effects of habitat disruption onthe activity of nectarivorous bats in a dry forest: Implications for the reproductive success of the Neotropical tree Ceiba grandiflora. Oecologia, 135, 400406.

135.Quesada, M., Stoner, K.E., Lobo, J.A., Herrerías-Diego, Y., Palacios-Guevara, C., Munguía-Rosas M.A., et al. (2004) Effects of forest fragmentation on pollinator activity and consequences for plant reproductive success and mating patterns in bat pollinated bombacaceous trees. Biotropica, 36(2), 131-138.

136. Ramirez, N., Sobrevila, C, Enrech, N. \& Ruiz-Zapata, T. (1984) Floral Biology and Breeding System of Bauhinia benthamiana Taub. (Leguminosae), a Bat-Pollinated Tree in Venezuelan "Llanos". Amer. J. Bot., 71(2), 273-280.

137.Reid, J.L., Holste, E.K. \& Zahawi, R.A. (2013) Artificial bat roosts did not accelerate forest regeneration in abandoned pastures in southern Costa Rica. Biol. Conserv., 167, 9-16.

138. Ritzi, C.M. \& Ritzi, C.M. (2001) The arthropod community in bat guano from an abandoned building in Presidio County, Texas. Texas J Sci, 53(1), 79-82.

139. Rivera-Marchand, B. \& Ackerman, J.D. (2006) Bat Pollination Breakdown in the Caribbean Columnar Cactus Pilosocereus royenii. Biotropica, 38(5), 635642.

140.Rocha, E.A., Machado, I.C. \& Zappi, D.C. (2007) Floral biology of Pilosocereus tuberculatus (Werderm.) Byles \& Rowley: a bat pollinated cactus endemic from the "Caatinga" in northeastern Brazil. Bradleya, 25, 12-144.

141.Rojas-Martínez, A.E., Pavón, N.P. \& Castillo, J.P. (2015) Effects of seed ingestion by the lesser longnosed bat Leptonycteris yerbabuenae on the germi- nation of the giant cactus Isolatocereus dumortieri. Southwest. Nat., 60(1), 85-89.

142. Romo, M.C. (1996) Seasonal variation in fruit consumption and seed dispersal by canopy bats (Artibeus spp.) in a lowland forest in Perú. Vida Silvestre Neotropical, 5(2),110-119.

143.Rosas-Guerrero, V., Aguilar, R., Martén-Rodriguez, S., Ashworth, L., Lopezaraiza-Mikel M, Bastida, J., et al. (2014) A quantitative review of pollination syndromes: do floral traits predict effective pollinators? Ecol. Lett., 17, 388-400.

144.Rossaneis, B.K., dos Reis, N.R., Bianchini, E. \& Pimenta, J.A. (2015) Seed germination after passing through gastrointestinal tract of bats (Chiroptera, Phyllostomidae). Semin. Ciênc. Biol. Saúde, 36(2), 3-14.

145. Sahley, C.T. (1996) Bat and Hummingbird Pollination of an Autotetraploid Columnar Cactus, Weberbauerocereus weberbaueri (Cactaceae). Am. J. Bot., 83(10), 1329-1336.

146. Sahley, C.T. (2001) Vertebrate pollination, fruit production, and pollen dispersal of Sternocereus thurberi (Cactaceae). Southwest. Nat., 46(3), 261-271.

147.Salazar, D., Kelm, D.H. \& Marquis, R.J. (2013). Directed seed dispersal of Piper by Carollia perspicillata and its effect on understory plant diversity and folivory. Ecology, 94(11), 2444-2453.

148. Saldaña-Vázquez, R.A., Castaño, J.H., Pérez-Torres, J. (2019) Does seed ingestion by bats enhance germination? A new meta-analysis 15 years later. Mammal. Rev., 49, 201-209.

149. Salgado, S.S., Motta, P.C., De Souza Aguiar, L.M. \& Nardoto, G.B. (2014) Tracking dietary habits of cave arthropods associated with deposits of hematophagous bat guano: A study from a neotropical savanna. Austral. Ecol., 39, 560-566.

150.Santiago-Hernández, M.H., Martén-Rodríguez, S., Lopezaraiza-Mikel, M., Oyama, K, González-Rodríguez, A. \& Quesada, M. (2019) The role of pollination effectiveness on the attributes of interaction networks: from floral visitation to plant fitness. Ecology, doi: 10.1002/ecy.2803.

151. Sato, T.M., Passos, F.C., \& Nogueira AC (2008) Frugivoria de morcegos (Mammalia, Chiroptera) em $\mathrm{Ce}$ cropia pachystachya (Urticaceae) e seus efeitos na germinação das sementes. Pap. Avulsos Zool., 48(3), 19-26.

152. Sazima, M. \& Sazima, I. (1978) Bat Pollination of the Passion Flower, Passiflora mucronata, in Southeastern Brazil. Biotropica, 10(2), 100-109. 
153.Sazima, M., Fabián, M.E. \& Sazima, I. (1982) Polinizacao de Luehea speciosa (Tiliaceae) por Glossophaga soricina (Chiroptera, Phyllostomidae). Rev. Bras. Biol., 42(3), 505-513.

154.Sazima, M., Buzato, S. \& Sazima, I. (2003) Dyssochroma viridiflorum (Solanaceae): a Reproductively Bat-dependent Epiphyte from the Atlantic Rainforest in Brazil. Ann. Bot., 92, 725-730.

155. Slauson, L.A. (2000) Pollination biology of two chiropterophilous Agaves in Arizona. Am. J. B., 87(6), 825-836.

156. Soriano, P.J. \& Ruiz, A. (2002) The Role of Bats in Reproduction of Columnar Cacti in the Northern Andes. In: T.H Fleming \& A. Valiente-Banuet (Eds.), Ecology, Evolution and Conservation of columnar cacti and their mutualists (241-263.). Tucson: Arizona University Press.

157. Studier, E.H., Boyd, B.C., Feld, A.T., Dapson, R.W. \& Wilson, D. (1983) Renal function in the Neotropical bat Artibeus jamaicensis. Comp. Biochem. Physiol., $75 \mathrm{~A}(2), 199-209$.

158. Studier, E.H. \& Wilson, D.E. (1983) Natural urine concentrations and composition in Neotropical bats. Comp. Biochem. Physiol., 75A(4), 509-515.

159.Studier, E.H., Viele, D.P. \& Sevick, S.H. (1991) Nutritional implications for nitrogen and mineral budgets from analysis of guano of the big brown bat Eptesicus fuscus (Chiroptera: Vespertilionidae). Comp. Biochem. Physiol., 100(4), 1035-1039.

160.Studier, E.H., Sevick, S.H., Ridley, D.M. \& Wilson, D.E. (1994) Mineral and nitrogen concentrations in feces of some neotropical bats. J. Mammal., 75(3), 674-680

161.Studier, E.H., Sevick, S.H., Keeler, J.O. \& Schenck, R.A. (1994) Nutrient Levels in Guano from Maternity Colonies of Big Brown Bats. J. Mammal., 75(1), 71-83.

162.Texiera, R., Correa, C. \& Fischer, E. (2009) Frugivory by Artibeus jamaicensis (Phyllostomidae) bats in the Pantanal, Brazil, Stud. Neotrop. Fauna Environ., 44(1), 7-15.

163.Thomas, D.W., Cloutier, D., Provencher, M. \& Houle, C. (1988) The Shape of Bird- and Bat-Generated Seed Shadows Around a Tropical Fruiting Tree. Biotropica, 20(4), 347-348.

164. Traveset, A. (1998) Effect of seed passage through vertebrate frugivores' guts on germination: a review. Perspect. Plant Ecol., 1, 151-19.

165. Traveset, A. \& Verdú, M. (2002) A meta-analysis of the effect of gut treatment on seed germination. In:
D.J. Levey, W. Silva \& M. Galetti (Eds.), Seed Dispersal and Frugivory Ecology, Evolution and Conservation (339-350). London: $\mathrm{CAB}$ International.

166.Tremlett, C.J., Moore, M., Chapman, M.A., Zamora-Gutierrezm V. \& Peh, K.S.-H (2019) Pollination by bats enhances both quality and yield of a major cash crop in Mexico. J. Appl. Ecol., 57(3), 450-459.

167.Tschapka, M. \& Dressler, S. (2002) Chiropterophily: on bat-flowers and flower bats. Curtis's bot Mag, 19(2), 114-125.

168. Tschapka, M. (2003) Pollination of the understorey palm Calyptrogyne ghiesbreghtiana by hovering and perching bats. Biol. J. Linn. Soc., 80, 281-288.

169. Tschapka, M. \& von Helversen, O. (2007) Phenology, nectar production and visitation behaviour of bats on the flowers of the bromeliad Werauhia gladioliflora in a Costa Rican lowland rain forest. J. Trop. Ecol., 23, 385-395.

170.Ulh, C., Clark, K., Clark, H. \& Murphy, P. (1981) Early Plant Succession after Cutting and Burning in the Upper Rio Negro Region of the Amazon Basin. J. Ecol., 69(2), 631-649.

171.Uieda, W. \& Vasconcellos-Neto, J. (1985) Dispersao de Solanum spp (Solanaceae) por morcegos, na regiao de Manaus, AM, Brasil. Rev. Bras. Zool., 2(7), 449458.

172. Valiente-Banuet, A., Arizmendi, M.C., Rojas-Martínez, A. \& Domínguez-Canseco, L. (1996) Ecological relationships between Columnar cacti and Nectar-Feeding Bats in Mexico. J. Trop. Ecol., 12(1), 103-109.

173. Valiente-Banuet, A., Rojas-Martínez, A., Casas, A., Arizmendi, M.C. \& Dávila, P. (1997) Pollination biology of two winter-blooming giant columnar cacti in the Tehuacán Valley, Central Mexico. J. Arid. Environ., 37, 331-341.

174. Valiente-Banuet, A., Rojas-Martínez, A., Coro Arizmendi, M. \& Dávila, P. (1997) Pollination biology of two columnar cacti (Neobuxbaumia mezcalaensis and Neobuxbaumia macrocephala) in the Tehuacan Valley, Central Mexico. Am. J. Bot., 84(4), 452-455.

175. Valiente-Banuet, A. (2002) Vulnerabilidad de los sistemas de polinización de cactáceas columnares de México. Rev. Chil. Hist. Nat., 75, 95-104.

176. Valiente-Banuet, A., Molina-Freaner, F., Torres, A., Arizmendi, M.C. \& Casas, A. (2004) Geographic differentiation in the pollination system of the columnar cactus Pachycereus pecten-aboriginum. Am. J. Bot., 91(6), 850-855. 
177. Valiente-Banuet, A., Gally, R.S., Arizmendi, M.C. \& Casas, A. (2007) Pollination biology of the hemiepiphytic cactus Hylocereus undatus in the Tehuacán Valley, Mexico. J. Arid. Environ., 68, 1-8.

178. Vázquez-Yanes, C., Orozco, A., Francois, G. \& Trejo, L. (1975) Observations on Seed Dispersal by Bats in a Tropical Humid Region in Veracruz, Mexico. Biotropica, 7(2), 73-76.

179. Vieira, M.F. \& Carvalho-Okano, M. (1996) Pollination Biology of Mabea fistulifera (Euphorbiaceae) in Southeastern Brazil. Biotropica, 28(1), 61-68.

180. Vleut, I., Levy-Tacher, S.I., Galindo-González, J. \& de Boer, W.F. (2015). Positive effect of surrounding rainforest on composition, diversity and late-successional seed dispersal by bats. Basic Appl. Ecol., 16, 308-315.

181. Voigt, C.C., Voigt-Heucke, S.L. \& Kretzschmar, A. (2012) Isotopic evidence for seed transfer from suc- cessional areas into forests by short-tailed fruit bats (Carollia spp.; Phyllostomidae). J. Trop. Ecol., 8, 181-186.

182. Voigt, C.C., Borissov, I. \& Kelm, D.I. (2015) Bats Fertilize Roost Trees. Biotropica, 47(4), 403-406.

183. Webster, J.M. \& Whitaker, J.O. (2005) Study of Guano Communities of Big Brown Bat Colonies in Indiana and Neighboring Illinois Counties. Northeast. Nat., 12(2), 221-232.

184. Whitaker, J.O., Clem, P. \& Munsee, J.R. (1991) Dame Trophic Structure of the Community in the Guano of the Evening Bat Nycticeius humeralis in Indiana. Am. Midl. Nat., 126(2), 392-398.

185. Williams-Guillén, K., Perfecto, I. \& Vandermeer, J. (2008) Bats limit insects in a neotropical agroforestry system. Science, 320, 70. 